University at Buffalo School of Law

Digital Commons @ University at Buffalo School of Law

\title{
Standard Setting in Human Rights: Critique and Prognosis
}

\author{
Makau Mutua \\ University at Buffalo School of Law
}

Follow this and additional works at: https://digitalcommons.law.buffalo.edu/journal_articles

Part of the Human Rights Law Commons, and the International Law Commons

\section{Recommended Citation}

Makau Mutua, Standard Setting in Human Rights: Critique and Prognosis, 29 Hum. Rts. Q. 547 (2007).

Available at: https://digitalcommons.law.buffalo.edu/journal_articles/564

Copyright (c) 2007 The Johns Hopkins University Press. This article was first published in Human Rights Quarterly 29.3 (2007), 547-630. Reprinted with permission by Johns Hopkins University Press.

\section{IN COPYRIGHT}

This Article is brought to you for free and open access by the Faculty Scholarship at Digital Commons @ University at Buffalo School of Law. It has been accepted for inclusion in Journal Articles by an authorized administrator of Digital Commons @ University at Buffalo School of Law. For more information, please contact lawscholar@buffalo.edu. 


\title{
Standard Setting in Human Rights: Critique and Prognosis
}

\author{
Makau Mutua*
}

\begin{abstract}
This article interrogates the processes and politics of standard setting in human rights. It traces the history of the human rights project and critically explores how the norms of the human rights movement have been created. This article looks at how those norms are made, who makes them, and why. It focuses attention on the deficits of the international order, and how that order-which is defined by multiple asymmetries-determines the norms and the purposes they serve. It identifies areas for further norm development and concludes that norm-creating processes must be inclusive and participatory to garner legitimacy across various divides.
\end{abstract}

\section{TABLE OF CONTENTS}

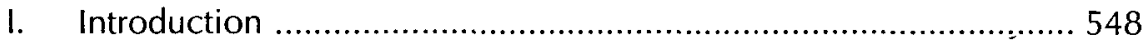

II. Norm-Setting in International Law and Human Rights ................ 550

A. Historical Antecedents ....................................................... 550

B. The Universal Declaration and the Promise of a Normative Foundation .................................................................... 552

* Makau Mutua is SUNY Distinguished Professor, Professor of Law, Floyd H. \& Hilda L. Hurst Faculty Scholar, and Director of the Human Rights Center at Buffalo Law School, State University of New York. Harvard Law School, S.J.D. 1987, LL.M., Harvard Law School; LL.M., University of Dar-es-salaam, 1984; LL.B., University of Dar-es-salaam, 1983.

The author wishes to thank Dr. Mohammad-Mahmoud Ould Mohamedou, the Associate Director of the Program on Humanitarian Policy and Conflict Research at the Harvard School of Public Health for his support and editorial assistance on this article. The article grew out of a research project that Dr. Mohamedou oversaw when he was Research Director at the Geneva-based International Council on Human Rights Policy. The author is indebted to Aleksandra Bojovic for her research assistance. 
III. The Process of Standard setting in Human Rights ...................... 557

A. Capturing Standards, Norms, and Rights ............................ 558

B. The Weight of Declarations ................................................. 562

C. New Difficulties in Human Rights Standard Setting .............. 565

D. Traditional Obstacles to Standard Setting ….......................... 569

E. Politics as Obstruction ....................................................... 573

F. The Ownership of Norms and Standards ............................ 575

G. Constituencies and Ownership ........................................... 578

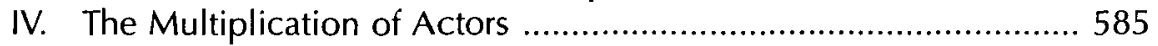

A. The UN Human Rights Council ........................................... 585

B. International and Regional Standard Setting .........................587

V. The Role of NGOs in the Creation of Norms ............................ 589

A. NGOs and the Human Rights Agenda ................................ 589

B. NGOs and Standard Setting ............................................. 594

C. NGO Strategies and Methods in Standard Setting ................. 599

D. NGOs and States Play Hide and Seek .................................. 602

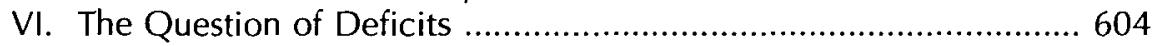

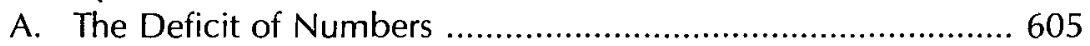

B. The Deficit of Participation ..................................................... 606

C. The Deficit of Democracy ................................................... 609

D. Language: Content and Implementation ..............................6 613

E. The Relationship Between Norms and Institutions ................. 613

F. Standard Setting and Implementation in Practice .................. 615

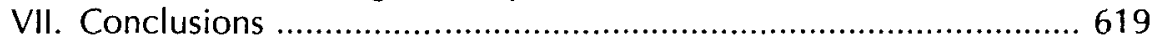

A. What is the Future of Standard Setting in Human Rights? ..... 619

B. The Quest for Standards in Economic and Social

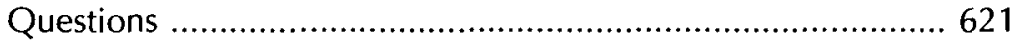

C. The Need for a Normative Framework on Disabilities ........... 623

D. Other Candidate Issues for Standards .................................6 626

E. Is There a Need for New Strategies? .....................................629

\section{INTRODUCTION}

In the past decade, the thinking has been that international action on human rights should move from setting legal standards to the implementation of existing standards. The usefulness of some new standards has been questioned, and there is evidence that disenchantment is growing. At its simplest, the issue is that treaty making in the area of human rights has, in some ways, become complicated, and even in cases where a text is adopted, there is no guarantee that the treaty is effective. Both governments and nongovernmental organizations (NGOs) are divided over the value of undertaking negotiations on new texts. Recent negotiations on particular standards-for example, the Optional Protocols to the Convention on the Rights of the Child and the 
Convention against Torture and Other Cruel, Inhuman or Degrading Treatment or Punishment-show that some states are reluctant to support new standards, even when ratification is optional.

This article examines the nature and recent evolution of international human rights standard setting processes. It analyzes the effectiveness of those processes, the role of different actors within those processes, and seeks to identify possible new avenues in standard setting. It also seeks to understand the processes involved in standard setting and draws lessons through the examination of different standards and their contexts. The aim is to provide analysis, guidance, and fresh thinking to human rights experts and human rights NGOs that seek to initiate or advocate for new human rights standards and officials in inter-governmental and governmental organizations that are involved in standard setting processes.

The article specifically examines the history and genesis of four cases where standards have been recently drafted or amended: the Optional Protocol to the Convention against Torture and Other Cruel, Inhuman or Degrading Treatment or Punishment; the Declaration on Human Rights Defenders otherwise known as the Declaration on the Right and Responsibility of Individuals, Groups and Organs of Society to Promote and Protect Universally Recognized Human Rights and Fundamental Freedoms; the Declaration on the Right to Development; and the Guiding Principles on Internal Displacement. The author consulted different actors involved in negotiations leading to the adoption of these instruments. Their insights were useful in allowing the research to draw conclusions in relation to each case study and, eventually, in relation to standard-setting in general.

Against this background, the article asks three primary sets of questions. The first set of questions asks: By what formal and informal processes have recent standards been established? What have been the strengths and weaknesses of those processes in different cases? The second set of questions asks: What lessons can be drawn? Which benchmarks are useful? Is there, as some have suggested, a proliferation of standards?' What strategic options should NGOs consider as they plan ahead? What new approaches should be explored in relation to standard setting? Should some of the resources that currently go into standard setting be focused elsewhere? If so, on what? The final set of questions asks: Which new standards are necessary and which are not, and why? Can organizations cooperate to agree on priorities and criteria? What constraints and opportunities need to be considered?

Section II of the article begins with a discussion of the central question of whether international action on human rights should move from setting

1. Nicolas Valticos, The Role of the ILO: Present Action and Future Perspectives in Human Rights: Thirty Years After the Universal Declaration 211, 216 (B.G. Ramcharan ed., 1979). 
standards to implementing existing standards. It then looks at the historical antecedents of the problem and the origins of the regime of the international human rights corpus, including an examination of the Universal Declaration of Human Rights as a normative foundation. Section III describes and analyzes the actual process by which standards are set. It looks at the different types of documents that are used to encapsulate norms, the weight of these different platforms, and the bargaining techniques, including obstruction, which characterize the process. Section III then considers the question of ownership of norms and the constituencies who stand behind the standards.

Section IV delves into the implications of the proliferation of actors in the standard setting process over the past several decades. It argues that the diversity of players has significantly influenced law making. Section $V$ closely examines the role of NGOs in relation to that process. It identifies the leading, but complex, role that NGOs often play in relation to the development and adoption of standards. Section VI addresses potential deficits in the process of identifying and adopting standards in relation to three specific deficits: numbers, participation, and democracy. Finally, Section VII identifies some areas where new standards might be needed and proposes some pointers for the betterment of the human rights standard-setting process.

\section{NORM-SETTING IN INTERNATIONAL LAW AND HUMAN RIGHTS}

\section{A. Historical Antecedents}

The normative regime of international human rights law originated in liberal theory and philosophy. The rise of the modern nation-state in Europe and its monopoly over violence and the instruments of coercion gave birth to a culture of individual rights to contain the abusive and invasive state. John Locke reduced this relationship between the state and the individual to a philosophy in his Two Treatises of Government. ${ }^{2}$ In liberal theory, individual rights act as a bar against the despotic proclivities of the state. It is on this theoretical foundation that international human rights law rises. Thus, the modern state is the primary guarantor of human rights, while it is at the same time the basic target for international human rights law. ${ }^{3}$ For several centuries, however, these normative limitations remained the exclusive province of constitutional and other domestic legal regimes. The creation of a binding system of international human rights law did not happen until

2. See John Locke, Two Treatises of Government (Peter Laslett ed., 1988).

3. Henry J. Steiner, The Youth of Rights, 104 HaRv. L. Rev. 917 (1991) (reviewing Louls Henkin, The AGe of Rights (1990)). 
after World War II-following the abominations of the Third Reich. Human rights law is therefore at its core an internationalization of the obligations of the liberal state.

To be certain, the post-war international human rights regime did not spring into existence overnight. It has its historical antecedents in a number of mass struggles, international law doctrines, and institutions. These include anti-colonial struggles, state responsibility for injuries to aliens, struggles against (and from) religious persecution, the Mandates and Minorities Systems of the League of Nations, the protection of minorities, humanitarian intervention, international humanitarian law, the struggle for women's rights, anti-slavery campaigns, and anti-apartheid and other anti-racist struggles.

In its original formulation, international law was the exclusive preserve of the Society of Nations. ${ }^{4}$ The responsibility for the initial construction of the basic principles of international law belonged to this small core of states. Standard setting and norm creation at the dawn of international law were therefore an exclusively European exercise. That is why the guts of the discipline of international law, as well as it's theoretical and philosophical predicates, are regarded as Eurocentric. ${ }^{5}$

International law, which was originally state-centered, exclusively governed relationships between nation-states. States alone made and applied international law. Thus, only a select few states were subjects of international law and therefore had any rights under this legal order. After World War I, however, several newly created international organizations were recognized as having some limited rights under international law. Generally, individual human beings did not have any international legal rights; as such, a state's treatment of its natural persons was not the business of any other state or of the international community.

With the passage of time, the individual started gaining currency in international law. The doctrine of humanitarian intervention, very early on in the development of international law, recognized "as lawful the use of force by one or more states to stop the maltreatment by a state of its own nationals when that conduct was so brutal and large-scale as to shock the conscience of the community of nations. ${ }^{6}$ Later, the individual gained more

4. James Crawford, The Criteria for Statehood in International Law, 48 BRIISH Y.B. INT'L L. 93, 98 (1976-77).

5. See, e.g., John Norton Pomeror, Lectures on International Law in Time of Peace 4-5 (Theodore Salisbury Woolsey ed., 1886); Herbert Arthur Smith, Great Britain and the Law of Nations 12 (1932-35); James Thuo Gathii, International Law and Eurocentricity, 9 Eur. J. INT'L L. 1, 184 (1998); Antony Anghie, Finding the Peripheries: Sovereignty and Colonialism in Nineteenth-Century International Law, 40 HARv. INT'L L. J. 1, 40 (1999); Antony Anghie, Francisco de Vitoria and the Colonial Origins of International Law, 5 Soc. \& LeGal. Stud. 321 (1996).

6. Thomas Buergenthal, et al., International Human Rights in a Nutshell 3 (3d ed., 2002). 
protection from the nineteenth century treaties to ban the trans-Atlantic slave trade in Africans and the conclusion of treaties to protect Christians in the Turkish (Ottoman) Empire.

In the early twentieth century, the League of Nations provided that colonial powers observe the "principle that the well-being and development" of native [colonized] peoples "form a sacred trust of civilisation." Covenant also called for "fair and humane conditions of labour for men, women, and children." 8 The International Labour Organization took up that challenge and produced a plethora of instruments on labor standards and worker's rights. The League also pushed for the development of an international system for the protection of minorities. International humanitarian law - the law of war-also provided for the care of the wounded or sick combatants and the protection of medical personnel and hospital facilities in wartime. ${ }^{9}$

While these international legal doctrines and institutions played a critical role in the early foundation of human rights norm-setting, popular mass struggles by marginalized groups and colonized peoples were no less important in giving content to the post-war human rights movement. Examples of these struggles are the anti-colonial and anti-racist movements by the peoples of Africa, Asia, the Pacific, the Caribbean, and Latin America. These struggles for self-determination and independence have left an indelible mark on human civilization. Apartheid in South Africa provided an early impetus for the international human rights movement, even before its formal codification after World War II. Similarly, the struggle for women's rights-for universal suffrage, equal treatment, and non-discrimination-in all parts of the world have been an indispensable building block in the normative development of the modern human rights movement.

\section{B. The Universal Declaration and the Promise of a Normative Foundation}

The United Nations and its Charter unleashed a torrent of norms, processes, and institutions in human rights. Even so, one should not overstress the universality of the United Nations as it stood in 1945. In popular history books, World War II is depicted as a contest between good and evil, with the victorious triumph of the former. However, the post-war international

7. League of Nations Covenant art. 22, available at http://www.yale.edu/lawweb/avalon/ leagcov.htm.

8. Id. art. 23.

9. Geneva Convention for the Amelioration of the Condition of the Wounded in Armed Forces in the Field, 12 Aug. 1949, arts. 1, 2, 6, 6 U.S.T 1864, 75 U.N.T.S. 31 (entered into force 21 Oct. 1950) (entered into force for U.S. 2 Feb. 1956). 
order is anything but equitable. Mohammed Bedjaoui, a Judge at the International Court of Justice, described the order as "scandalous." ${ }^{10}$ The difficulties lie in: (i) the inherent inequalities within the structures of international governance; (ii) the asymmetries of power between the North and the South; (iii) the imbalances between states in the global economy; and (iv) the lopsided military domination of the world by the United States. These inequities find their expression in the setting of international standards and their enforcement.

At its inception, the United Nations was not representative of the global communities for whom it purported to speak. In 1945, the UN was launched with fifty-one states as its members-many from Europe and the Americas. Most African, Asian, and Pacific states were still European colonies. Under the leadership of the United States, the West dominated the United Nations, and the new international order forged out of the ashes of World War II. Symptomatic of Western domination was its commanding presence in the UN Security Council, the central and most important organ of the United Nations." Paradoxically, the Preamble of the UN Charter states, in part, that it reaffirms "[f]aith in fundamental human rights, in the dignity and worth of the human person, in the equal rights of men and women and of nations large and small."12

One of the purposes of the United Nations is to "[a]chieve international co-operation in solving international problems of an economic, social, cultural or humanitarian character, and in promoting and encouraging respect for human rights and for fundamental freedoms for all without distinction as to race, sex, language or religion. ${ }^{\prime 13}$ The UN Charter reiterates this ideal when it emphasizes that it shall promote "[u]niversal respect for and observance of human rights and fundamental freedoms for all without distinction as to race, sex, language or religion."14 Despite its structural inequalities, the new international order aspired to the principles of sovereign equality, anti-discrimination, and equal protection. It was into this world that the Universal Declaration of Human Rights (UDHR), arguably the most important human rights instrument, was born on 10 December 1948. Forty-eight states unanimously adopted the UDHR, with eight abstentions. It is instructive that a narrow membership of the UN at the time-a mere

10. Mohamed Bedjaoui, Towards a New International Economic Order 66 (1979).

11. The UN Security Council is the only organ of the United Nations with the power to authorize the use of force and to make binding decisions on all member states. The Security Council has five permanent members: Russia, China, France, the United States, and Great Britain - who each hold a veto power. See U.N. ChARTER arts. 23, 24, 25, 27, 39, 42, signed 26 June 1945, 59 Stat. 1031, T.S. No. 993, 3 Bevans 1153 (entered into force 24 Oct. 1945).

12. Id. Pmbl.

13. Id. art. 1(3).

14. Id. art. 55(c). 
fifty-six states-proclaimed the UDHR "a common standard of achievement for all peoples and all nations." ${ }^{\prime 15}$

There appears to be consensus within the UN and among states, academics, and human rights advocates that the UDHR is the most significant embodiment of human rights standards. It has been described as "showing signs of having achieved the status of holy writ within the human rights movement." ${ }^{\prime 16}$ Elsewhere, the UDHR has been described generously as the "spiritual parent" of other human rights documents. ${ }^{17}$ Henry Steiner and Philip Alston, two intellectual leaders of the human rights movement, also call it "the parent document, the initial burst of idealism and enthusiasm, terser, more general and grander than the treaties, in some sense the constitution of the entire movement ... the single most invoked human rights instrument." ${ }^{18}$ In short, the UDHR is the normative foundation of the human rights movement, the instrument that became the standard-bearer for the entire enterprise.

Despite the wonderful promise the UDHR offered, serious limitations accompanied the dawn of the international human rights movement. The narrow club of states in the UN at the time seriously compromised the normative universality of the movement's founding document. Antonio Cassese, the former President of the International Criminal Tribunal for the Former Yugoslavia, wrote that the West imposed its philosophy of human rights on the rest of the world because it dominated the United Nations at its inception. ${ }^{19}$ As noted in 1947 by the American Anthropological Association, one of the few NGO bodies to express their view on the impending international Bill of Rights, the promulgation of a universal human rights instrument would be extremely difficult. The Association noted in part:

The problem of drawing up a Declaration of Rights was relatively simple in the Eighteenth century, because it was not a matter of human rights, but of the rights of men within the framework of the sanctions laid by a single society. . . Today, the problem is complicated by the fact that the Declaration must be of world-wide applicability. It must embrace and recognize the validity of many different ways of life. It will not be convincing to the Indonesian, the African, the Indian, the Chinese, if it lies on the same plane as like documents of an earlier period. ${ }^{20}$

15. Universal Declaration of Human Rights, adopted 10 Dec. 1948, G.A. Res. 217A (III), U.N. GAOR, 3d Sess. (Resolutions, pt. 1), at 71, pmbl., U.N. Doc. A/810 (1948), reprinted in 43 AM. J. INT'L L. 127 (Supp. 1949) (hereinafter UDHR].

16. Mary Ann Glendon, Knowing the Universal Declaration of Human Rights, 73 Notre Dame L. Rev. 1153, 1153 (1998).

17. Henry J. Steiner, Political Participation as a Human Right, 1 Harv. Hum. Ris. Y.B. 77, 79 (1988).

18. Henry J. Steiner \& Philip Alston, International. Human Rights in Context: Law, Politics, Morals 120 (1996).

19. Antonio Cassese, The General Assembly: Historical Perspective 1945-1989, in THE UNITED Nations and Human Rights: A Critical Appraisal 25, 31-32 (Philip Alston ed., 1992).

20. American Anthropological Association, Statement on Human Rights, 49 AM. ANTHROPOLOCIST 539 (1947). 
The American Anthropological Association pointed out correctly the risks of constructing universal norms and standards, and it cautioned that the cross-cultural legitimacy of any such enterprise would lie in a truly democratic, diverse, and participatory exercise. If the drafters assumed-as had hitherto been the case-that the West was the entirety of humanity, then the Universal Declaration would not resonate in cultures outside the European West. While the composition of the UN Commission on Human Rights, the body that drafted the UDHR, attempted to be culturally and geographically inclusive, the exclusivity of the United Nations sharply limited its membership pool. Theo van Boven has suggested that it was pretentious of the drafters of the UDHR to call it "universal" when a "large part of the world was still under colonial rule and therefore unable to participate in the framing of the document. ${ }^{\prime 21}$

The Commission was led by Eleanor Roosevelt and included such diplomats as Charles Malik of Lebanon and P.C. Chang of China. ${ }^{22}$ Some writers have pointed to these two prominent non-Westerners as evidence of the universality of the Commission's composition, hence the cross-cultural legitimacy of the UDHR. Yet Malik was a Christian, and both he and Chang were rooted firmly in Western liberal conceptions of the individual and the purposes for political society. Both had their formative education in the United States. As correctly noted by Abdullahi Ahmed An-Na'im, "all normative principles ... are based necessarily on specific cultural and philosophical assumptions." ${ }^{23} \mathrm{He}$ concludes that "given the historical context within which the present standards have been formulated, it was unavoidable that they were initially based on Western cultural and philosophical assumptions." ${ }^{24}$

Other analysts, like Bertrand Ramcharan, argue that it is a misunderstanding of history to say that the UDHR was a product of Western countries, as this denigrates the contribution of the majority of the members of the first Commission on Human Rights who came from Africa, Asia, Latin America, and Eastern Europe. ${ }^{25}$ According to him, it also denies the contribution to

21. Theo van Boven, United Nations Policies and Strategies: Global Perspectives? in Human Rights: Thirty Years after the Universal Declaration, supra note 1, at 83, 91.

22. See Mary Ann Glendon, A World Made New: Eleanor Roosevelt and the Universal Declaration of Human Rights 33 (2001).

23. Abdullahi An-Na'im, Conclusion, in Human Rights in Cross-Cultural Perspectives: A Quest for Consensus 427-28 (Abdullahi An-Na'im ed., 1992).

24. Id.

25. Bertrand Ramcharan, Human Rights: Universality and Cultural Diversity in RENDERING Justice to THE VulNerabie 239-58 (Fons Coomans et al, eds., 2000). Elsewhere, Ramcharan has asserted that development strategies need to be influenced in their conception and implementation by international human rights norms. He identified that the way forward for human rights rests on three conceptual pillars, the first of which is maintaining the United Nations consensus on the universality of human rights. See Bertrand Ramcharan, Human Rights and Human Security, paper prepared for the Workshop on Relationship Between Human Rights and Human Security, San José, Costa Rica (2 Dec. 2001), available at http://www.humansecurity-chs.org/activities/outreach/ramcharan.html. 
the intellectual patrimony of the world of those earlier, pre-Western societies in Asia and Africa, which developed the core ideas of freedom, democracy, and support for the rule of law. The argument is that while the application of these ideas may have evolved over time, their fundamental values and appeal remain universal. Ramcharan suggests that in essence the current debate regarding the universality of rights is more a political debate about power between the industrialized and industrializing countries than one of cultural relativism. ${ }^{26}$ This view suggests that cultural diversity might influence the way in which human rights might be applied by different societies, but the underlying tenets remain the same. ${ }^{27}$

It is now an established fact that Western cultural and political norms dominated the early formulation and codification of human rights standards. ${ }^{28}$ These ethnocentric limitations notwithstanding, the UDHR is largely a plausible document. It laid the foundation for the later development of both civil and political rights, as well as economic, social, and cultural rights. In this respect, the UDHR should be seen more as a credible promise than a holy text. Parts of the UDHR have entered into the rarefied stratosphere of customary international law, while the rest of it has achieved enormous moral authority. ${ }^{29}$ The UDHR, a declaration and not a treaty, is the most important human rights instrument. ${ }^{30}$

Soon after 1945, the exclusivity of the United Nations would be challenged by decolonization, a phenomenon that would transform age-old assumptions about the relationship between the North and the South. By the close of the twentieth century, the United Nations would have more than 190 member states. Law making - and standard setting-within the corridors of the UN and in the human rights arena would have to respond to a more diverse world, thus rendering the process far more complex.

26. Ramcharan, Human Rights: Universality and Cultural Diversity, supra note 25, at 239-58.

27. Nicolas Valticos has stated that questioning the universality of human rights is "dangerous ... skeptical relativism," tantamount to admitting that there should be "sub-standards for sub-humans." However, he sees a (limited) role for regional organizations on matters of regional interest, which would supplement the universal standards or provide stimulus to subsequent universal action. See Nicolas Valticos, The Role of the ILO: Present Action and Future Perspectives, in Human Rights: Thirty Years After the Universal Declaration, supra note 1, at 213-14.

28. Virginia Leary, The Effect of Western Perspectives on International Human Rights, in Human Rights in Africa: Cross-cultural Perspectives 15 (Abdullahi A. An-Na'im \& Francis Deng eds., 1990); Jomannes Morsinx, The Universal Declaration of Human Rights: Origins, DRAFTING, AND INTENT X-Xi (1999).

29. BUERGENTHAL ET AL., supra note 6, at 38-43.

30. Henry J. Steiner, Securing Human Rights: The First Half Century of the Universal Declaration, and Beyond, Harvard Magazine 45 (Sept.-Oct. 1998). 


\section{THE PROCESS OF STANDARD SETTING IN HUMAN RIGHTS}

The process of standard setting at the international level suggests complexity, negotiation, and consensus building. It also calls into play competing national interests, cultures, and ideologies. As if these questions were not enough, more difficult matters of the asymmetry of power, the ability to participate effectively in the process, and the capacity to own both the process and the product come into play. Unpacking process, therefore, is a tricky and pivotal question. For it is quite often the case that control over the process makes the final outcome predictable and, sometimes, moot. Where complex and competing players exist, the process becomes as essential as the product itself. Thus, questions must be asked about fairness, transparency, ownership, democracy, and participation in any probing discussion of process.

There is, moreover, a tendency by those involved in the human rights project to use the terms "standard," "norm," and "right" interchangeably as though they were synonymous or have an identical meaning. Other terms with similar connotations, such as "entitlement" or "claim," are sometimes thrown in. All these terms conjure up the following images: ideal, threshold, floor, benchmark, aspiration, and privilege. They suggest things that should be striven for and imply an expectation of the fulfillment of a promise or a duty. However, because the human rights corpus is a species of international law-essentially a legal regime that binds states-it is imperative that analyses of the terms adopt a precise legal lens. The language of the law seeks precision about the legal meaning of words and determines their legal status and the nature of the obligations or privileges it envisages. In fact, it can be plausibly argued that the process of standard setting in human rights is a struggle over the meaning of language and its implications on the conduct of states. Perhaps the most elastic of these terms is the word "standard" itself, which has no particular legal meaning and does not necessarily imply a legal obligation of any kind. A standard is a vacuous, empty receptacle into which one can fit almost anything. It refers to a level of achievement or expectation that may carry with it moral, cultural, or other civilizational aspiration.

The UDHR, for example, which was initially only meant to carry moral authority referred to itself as a "common standard of achievement for all peoples and all nations." ${ }^{\prime 31}$ It is almost certain that the UDHR would not have acquired its current authority had it been a legally binding instrument. It is in the flexibility of the term standard that lies hidden therein its wide reach and scope. It can be argued that freeing the term from the narrow strictures of the law gives it more authority and propels it to the forefront as a universal civilizational value that knows no cultural or geographic bound-

31. UDHR, supra note 15, pmbl. (Emphasis added.) 
ary. In other words, a standard is a phenomenon that is above a mere legal rule; it is an inherent and self-revealing virtue, one that demands obedience without question. There are advantages, therefore, to employing the looseended term particularly if one seeks a wider consensus without any obvious or immediate legal bond.

The term "norm" is more complicated than "standard" although it, too, has the advantage of transcending the narrow confines of the law. A "right" is the most crystallized of all these terms. It is the element that is laid bare once the other terms-standard and norm-are boiled down to their simplest forms. Arguably the single most important term in any legal regime, the word "right" is the foundation and basis of the human rights movement. In human rights discourse, rights provide the avenues through which human dignity is secured and guaranteed. The term implies both a duty and the bearer of that duty. In human rights law, the state bears the primary duty of protecting rights, which are enjoyed by individuals and groups. A right is viewed as an entitlement. ${ }^{32}$

While the rule of law is the bar between tyranny and democracy, human rights are the most sacred of all legal entitlements. Once a claim achieves the status of a human right, it acquires the aura of irreversibility, irrevocability, timelessness, and universal validity. Human rights are regarded as the zenith of human civilization. A human right is a crystal and clear phenomenon, an attribute that lacks the hazy outlines of a standard or a norm. It is in this respect that a right-in this case a human right - is a clear distillation and a more careful use of terminology than the more general "norm" or "standard." It is, therefore, important to note that the term standard encompasses both norms and rights. That is why the process and exercise of the creation of expectations and obligations in human rights can be referred to as standard setting, an expression that covers both binding and non-binding rules and codes of conduct.

\section{A. Capturing Standards, Norms, and Rights}

The situation of internally displaced persons (IDPs) is a major contemporary problem. By some estimates, there are twenty-five million IDPs worldwide, virtually all in conflict zones or in dictatorial, authoritarian, or war-torn states. ${ }^{33}$ The Guiding Principles on Internal Displacement define IDPs thus:

32. Ronald Cohen, Endless Teardrops: Prolegomena to the Study of Human Rights in Africa in Human Rights and Governance in Africa 3, 3-4 (Ronald Cohen et al., eds., 1993).

33. Report of the Representative of the Secretary General, Mr. Francis M. Deng, submitted pursuant to Commission Resolution 1997/39, U.N. ESCOR, Comm'n on Hum. Rts., 54th Sess., Provisional Agenda Item 9(d), U.N. Doc. E/CN.4/1998/53/Add.2 (11 Feb. 1998); Norwegian Refugee Council, Internally Displaced People: A Global Survey 3 (2002). 
[1]nternally displaced persons are persons or groups of persons who have been forced or obliged to flee or to leave their homes or places of habitual residence, in particular as a result of or in order to avoid the effects of armed conflict, situations of generalized violence, violations of human rights or natural or human-made disasters, and who have not crossed an internationally recognized border. $^{34}$

Like victims of traditional human rights violations, IDPs do not directly trigger international consequences. They are confined within the borders of their nation of origin and residence. Nonetheless, international law has taken an interest in the plight and deep suffering of IDPs because they are usually neglected or abused by their own states. IDPs also warrant international concern because they can-and often do-cause insecurity and instability in entire regions. As noted by the Norwegian Refugee Council:

These people [IDPs] are forced to seek safety not through asylum in a second state, but before their own governments and within the confines of national borders. The welfare of internally displaced populations has become the subject of international attention because the governments legally accountable for their care and protection are often unable or even unwilling to act on their behalf. Indeed, in many cases, the government in question is at least partly if not wholly responsible for the displacement of its citizens in the first place. ${ }^{35}$

Internally displaced persons (IDPs) are not per se the subject of any particular treaty or declaration. Prior to the appointment in 1992 of a Representative of the UN Secretary General on Internally Displaced Persons (Francis Deng), ${ }^{36}$ no particular specialized office within the United Nations system focused on IDPs. The UN had, however, been preoccupied with refugee matters for decades. However refugee law, while it offers useful lessons to a regime for the treatment of IDPs, it applies only to persons who have crossed an international border. It does not apply to IDPs. As noted by Deng, "[IDPs] . . . have been forced to leave their homes and find themselves in refugee-like situations." ${ }^{37}$ As such, "refugee law, by analogy, can be useful in proposing rules and establishing guidelines to protect the needs of the internally displaced." ${ }^{\prime 38}$ It is not, however, the legal framework for addressing IDPs.

34. Id. I 1.

35. Norwegian Refugee CounciL, supra note 33 , at 3.

36. Walter Kälin, who was appointed in 2004 to be the Representative of the UN Secretary General on Internally Displaced Persons, is the current UN Secretary General on Internally Displaced Persons.

37. Compilation and Analysis of Legal Norms: Report of the Representative of the SecretaryGeneral, Mr. Francis M. Deng, submitted pursuant to Commission on Human Rights Resolution 1995/57, U.N. ESCOR, Comm'n on Hum. Rts., 51 st Sess., Provisional Agenda Item 9(d), ๆ 25, U.N. Doc. E/CN.4/1996/52/Add.2 (1995).

38. Id 
The United Nations Commission on Human Rights asked the Special Representative on IDPs to determine the extent to which existing legal regimes-human rights, humanitarian law, and refugee law-provided a basis for the protection of IDPs. He produced the Internally Displaced Persons: Compilation and Analysis of Legal Norms, ${ }^{39}$ which examined international human rights law, humanitarian law, and refugee law and concluded that while all these disparate regimes provided substantial coverage for IDPs, significant gaps and failures in protection existed. In particular, the Special Representative identified weaknesses related to "the need for an expressed right not to be unlawfully displaced, to have access to protection and assistance during displacement and to enjoy a secure return and re-integration." 40

The UN General Assembly and the Commission on Human Rights asked that the Special Representative's report be made available widely and then mandated him to "develop an appropriate framework, on the basis of the Compilation and Analysis, for the protection and assistance of internally displaced persons." ${ }^{41}$ The Special Representative developed the Guiding Principles on Internal Displacement as a response to this mandate. The Guiding Principles are an attempt to harmonize the different legal regimes and to fill the normative gaps in the protection and assistance of IDPs. Why did the Special Representative develop Guiding Principles-a legal form without the force of the law, instead of pushing for a treaty or a declaration-a single definitive instrument-on IDPs?

There is no single human rights instrument addressing IDPs, so many expected that the Special Representative on IDPs would opt for a convention or a declaration. Even if substantial protections existed in disparate legal regimes - in humanitarian law, human rights law, and refugee law-it was felt by advocates of IDPs that the lack of a binding instrument on IDPs was an impediment to their protection..$^{42}$ The Special Representative and his team of legal experts reached a different conclusion for a variety of reasons. Two of these have been cited as the main rationale behind this decision.

First, the Special Representative and his experts argued that the Guiding Principles would produce in a short time a normative framework "while the elaboration of a treaty or declaration would lead to prolonged negotiations

39. Id.

40. Internally Displaced Persons: Note by the Secretary General, U.N. GAOR, 52d Sess., Agenda Item 112(c), I 3, U.N. Doc. A/52/506 (1997).

41. Human Rights Questions: Human Rights Situations and Reports of Special Rapporteurs and Representatives, U.N. GAOR, 51 st Sess., Agenda Item 110(c), I 4, U.N. Doc. A $51 / 843$ (1996).

42. Walter Kälin, How Hard is Soft Law? The Guiding Principles on Internal Displacement and the Need for a Normative Framework, in Recent Commentaries about the Nature and application of the Guiding Principles on Internal Displacement 1, 3 (Apr. 2002) /hereinafter Recent Commentaries on Guiding Principles]. 
affecting or even blocking the possibility of using international human rights law effectively in the context of internal displacement for a long time." ${ }^{\prime 43}$ $\mathrm{He}$ felt that states might either block a treaty or declaration, prolong their negotiation, or even water down existing and recognized legal protections. Second, the Special Representative and his team thought that a document that restated and reflected existing international law would be "sufficient to provide the necessary guidance to states, international agencies, NGOs and others dealing with IDPs." ${ }^{44}$ Since the existing law was largely sufficient--so the argument went-why not merely restate it in a non-binding document instead of plunging into uncertain and risky waters, leaving the fate of IDPs exposed and open to the whims of states? The gamble was that states would find the Guiding Principles more palatable because ostensibly they did not create new norms or additional obligations.

In 1998, two years after he was asked to produce a normative framework for IDPs, the Special Representative submitted the Guiding Principles to the Commission on Human Rights. The speed with which the Special Representative produced the Guiding Principles was impressive. Rarely do international human rights instruments get realized that fast. By avoiding the lengthy negotiating processes with states at the UN-and opting for a closed circuit of legal academics and other experts-the Special Representative circumvented the traditional processes of standard setting.

The Special Representative manipulated the language to restate existing legal obligations. Thus, instead of "rights" he uses the term "principles," but there is no doubt that the Guiding Principles refer to the "rights" of IDPs and the "binding obligations" of states with respect to IDPs. Nor is there a doubt that the Guiding Principles represent the single most comprehensive instrument and would be the basis of any future convention on IDPs, if ever there were enough political will to adopt one. Although he does not explicitly say so, the Special Representative clearly engaged in standard setting when he drafted and produced the Guiding Principles.

Generally, the Guiding Principles have been well received by a number of states, even though they could be viewed as a subversion of the established standard setting processes in human rights within the United Nations. To be fair to the Special Representative, the Commission on Human Rights did not ask him to propose a legal text of a treaty or declaration but rather requested him to "develop an appropriate framework"45 for the protection of IDPs. What is clear is that the Special Representative kept the UN

\footnotetext{
43. Id. at 4 .

44. Id.

45. Human Rights Questions, supra note 41. This resolution called on the "representative [of the Secretary General] to continue, on the basis of the compilation and analysis, to develop an appropriate framework in this regard for the protection of internally displaced persons."
} 
General Assembly and the Commission on Human Rights fully informed of his work in the execution of his mandate. The Special Representative "regularly reported on the views expressed on the Guiding Principles by Governments and intergovernmental and nongovernmental organizations, and on the efforts taken by them to promote, disseminate and apply the Guiding Principles." 46

Although the Guiding Principles have been demeaned by several states as non-binding, they have won the acclaim and support of many, including the UN General Assembly, the European Union, states in Central and Eastern Europe, Africa, the Americas, and Asia. ${ }^{47}$ These endorsements by such a wide and diverse array of states give the Guiding Principles a strong moral standing. Their increasing stature as a normative framework is underscored by the reported enthusiasm with which national, regional, and other international institutions continue to receive and promote them. ${ }^{48}$

It is clear, even to skeptics, that the Guiding Principles have been a success. National, regional, and international bodies-state, non-state, and inter-governmental - have sought training on the use of the Principles. They are quickly becoming the standard by which the rights of IDPs are being promoted and protected. Almost overnight, the Guiding Principles have revitalized interest in IDPs and made them an urgent concern of the international community. ${ }^{49}$

\section{B. The Weight of Declarations}

The most important declaration in human rights, and arguably in all of international law, is the UDHR. Yet the UDHR is only the first of many such instruments in human rights. Since the UDHR's adoption there have been a slew of declarations covering a wide range of concerns. These include the 1998 Declaration on Human Rights Defenders, ${ }^{50}$ the 1986 Declaration on the Right to Development, ${ }^{51}$ the 1994 Draft Declaration on the Rights

46. See Specific Groups and Individuals: Mass Exodus and Displaced Persons: Report of the Representative of the Secretary-General on internally displaced persons, Mr. Francis $M$. Deng, submitted pursuant to Commission on Human Rights Resolution 2001/54, U.N. ESCOR, Comm. On Hum. Rts., 58th Sess., Provisional Agenda Item 14(c), I 11, U.N. Doc. E/CN.4/2002/95 (2002).

47. Id. I $112-20$.

48. Id. I I 21-54.

49. Norwegian Refucee Council, supra note 33, at 17.

50. Declaration on the Right and Responsibility of Individuals, Groups and Organs of Society to Promote and Protect Universally Recognized Human Rights and Fundamental Freedoms, G.A. Res. 53/144, adopted 8 Mar. 1999, U.N. GAOR, 53 rd Sess., U.N. Doc. AVRES/53/144 (1999) [hereinafter Declaration on Human Rights Defenders].

51. Declaration on the Right to Development, G.A. Res. 41/128, adopted 4 Dec. 1986, U.N. GAOR, 41st Sess., U.N. Doc. ARRES/41/128 (1986). 
of Indigenous Peoples, ${ }^{52}$ and the 1993 Declaration on the Elimination of Violence Against Women. ${ }^{53}$ Typically, UN declarations in the human rights field have been adopted on those questions where a treaty or some other binding instrument would be difficult to achieve.

Two declarations discussed below-on development and human rights defenders-underline the complexity of standard setting. Both declarations have traveled checkered routes. One, the Declaration on the Right to Development, has been mired in a normative swamp, unable to claim a definitive jurisprudence or an academic consensus on its meaning and contours. The other, the Declaration on Human Rights Defenders, came to maturity only after a long period, and the early evidence points to difficulties of implementation. All these declarations, and in particular the Draft Declaration on the Rights of Indigenous Peoples, are a testimony to the obstinacy of states when they feel threatened by an international human rights instrument. Not even the use of less constraining language-a declaration as opposed to a treaty - will cause states to be less obstructionist in the setting of certain standards.

The UN Commission on Human Rights first asserted the existence of a right to development in $1977 .{ }^{54}$ In 1986, the General Assembly adopted the Declaration on the Right to Development. In 1993, the Vienna World Conference on Human Rights declared that the right to development is "a universal and inalienable right and an integral part of fundamental human rights. ${ }^{\prime 55}$ Since 1986, the Commission struggled to clarify the meaning and content of the right to development, including shedding light on whether the right has a legal status and what such status entails in terms of state responsibility.

The Commission set up working groups and, in 1998, appointed Arjun Sengupta the independent expert to lead the way in the clarification and implementation of the right to development. However, opposition to the right has come from some states, which see the global redistributive justice discourse of the right to development as incompatible with free market and capitalist structures of the global economy. In any event, a quarter century after it was mooted, the right to development still nags at the human conscience. "[E]xtensive efforts to clarify its [right to development] content and,

52. Draft Declaration as Agreed Upon by the Members of the Working Group at its Eleventh Session, U.N. ESCOR, Comm. On Hum. Rts., Sub-Comm. On Prevention of Discrimination and Protection of Minorities, 45th Sess., Agenda Item 14, U.N. Doc. E/CN.4/Sub.2/1994/2/Add.1 (1994).

53. Declaration on the Elimination of Violence against Women, G.A. Res. 48/104, adopted 20 Dec. 1993, U.N. GAOR, 48th Sess., U.N. Doc. ARES/48/104 (1994).

54. C.H.R. Res. 4 (XXXIII), U.N. ESCOR, Comm'n on Hum. Rts (21 Feb. 1977).

55. Vienna Declaration and Programme of Action, U.N. GAOR, World Conf. on Hum. Rts., 48th Sess., 22d plen. mtg., part I, I 10, U.N. Doc. A/CONF.157/24 (1993), reprinted in 32 I.L.M. 1661 (1993) [hereinafter Vienna Declaration!. 
more importantly, its implications, have yielded little agreement on concrete issues. . . . While many reports have been produced, they have yet to lead to any consensus about the practical consequences of the recognition of the right." ${ }^{\prime 5}$

It is not so much a matter of language that has bedeviled the right to development. The basic problem in the elaboration and implementation of the right arises from the nature of that right, not the instrument or the language in which it is embodied. It would have been impossible, in any case, for the UN to adopt a treaty on the right to development given the reluctance of powerful states to support it. Even though the right to development appears to be stuck in the cogs of international governance, the issues that it raises resonate even more loudly in this era of globalization. The language of development-and the expectation that poverty and want must be done away with or sharply reduced-is part of the discourse and consciousness of the world today. Development-and the seemingly fuzzy right to it-is a standard that is an important part of the human rights normative structure.

Similarly, the Declaration on Human Rights Defenders was not an easy standard to elaborate and implement. Adopted in 1998, it took the UN Working Group thirteen long years to produce the draft. The slow process in the completion of the Declaration has been attributed to two major factors. First, there was tension and friction between the states that supported an instrument on human rights defenders and those that were opposed to it. ${ }^{57}$ The latter group used the drafting process to delay, and hopefully thwart, the project altogether. Second, the consensus approach adopted allowed a small group of states to veto and delay any meaningful steps to finalize the draft. ${ }^{58}$

Although the Declaration on Human Rights Defenders was not a binding instrument-and in fact only restated rights that are enshrined in other principal human rights treaties and documents-it still elicited opposition from a number of states. The contentious issues were: the relationship between national law and the Declaration in its implementation; whether the Declaration gave human rights defenders any special responsibilities or duties; the right of defenders to access and obtain resources, including funding, for their work; the right to observe trials; the right to act on behalf of the victims of human rights violations; and the ability of human rights defenders to freely determine and choose what issues to focus and work on. ${ }^{59}$ Despite these questions, the New York-based Human Rights First (formerly Lawyers Committee for Human Rights) pronounced itself happy with the document.

56. Steiner \& Alston, International Human Rights in Context, supra note 18, at 1325.

57. Lamyers Committef for Human Rights, Protectinc Human Richts Defenders (1999).

58. Id.

59. Id. 
"In reviewing the Declaration," it noted, "our overall assessment is a very positive one. The Declaration is the first UN instrument to emphasize that everyone has the right to promote, protect and defend human rights, on the national and international levels." 60

NGOs, whose work it is to promote and protect human rights, invested a lot of time, influence, energy, and resources to push for the drafting and adoption of the Declaration. Nevertheless, many NGOs, and the governments that supported them, knew that they could not get states to agree to a treaty because all the rights they wanted were already internationally recognized human rights. It was a triumph, however, for the NGOs to get a mandate that was entrusted to Hina Jilani, a Pakistani human rights activist, as the UN Special Representative on Human Rights Defenders.

Kofi Annan, the UN Secretary General, appointed Jilani Special Representative on Human Rights Defenders in August 2000 after the UN Commission on Human Rights created the post in a resolution. Jilani was mandated to oversee the implementation of the Declaration by states. The resolution creating the mandate asks states to cooperate with, and assist, the Special Representative in the performance of her duties, which include monitoring and intervening in cases of the harassment of human rights monitors and defenders and pressing for the implementation of the Declaration. Jilani has conducted fact-finding and diplomatic missions, published reports on the conditions of human rights defenders, and has lobbied states to honor their obligations under the Declaration.

Due to the fact NGOs feel that they "own" this mandate by having advocated for it and becoming its primary beneficiaries, they have raised funds to support it. There are generally scarce funds to support the activities of the various UN Special Representatives; as such, the more enterprising appointees mobilize their constituencies for support. In her tenure, Jilani has produced several reports. ${ }^{61}$ Her mandate will only remain effective if NGO enthusiasm and a sense of ownership are kept up.

\section{New Difficulties in Human Rights Standard Setting}

There is an emerging consensus, perhaps even a self-fulfilling prophecy among academics and activists, that standard setting in human rights has become relatively more difficult in the last decade. This appears to be the case with respect to negotiations on some treaties or other binding human

60. Id.

61. Report by the Special Representative of the Secretary General on Human Rights Defenders, in Accordance with General Assembly Resolution 56/163, at 4, U.N. Doc A/57/182 (June 2004). 
rights instruments. The difficulties were traced to the fifty-three-member UN Commission on Human Rights, although ultimately the resistance was a manifestation of the changed geopolitical makeup since the end of the Cold War. Walter Kälin, a member of the UN Human Rights Committee, has noted that "unlike during the decades before 1990, it is no longer possible to adopt a text once the big powers have found a compromise." He attributes this problem to the "rapidly growing plurality of ideas and positions among states on human rights since the end of the cold war." ${ }^{\prime 62}$

There are competing interpretations of this development. One view is that the diversity of independent voices in the formulation of human rights must be a positive development, even if it results in delays in finding an agreement. Such diversity of opinions may also point to a more genuine end product, one that is more universal and which is bound to find more acceptance and legitimacy in many regions of the world.

The end of the West-East conflict has liberated former satellite states from the ideological tyranny of their respective sponsors, making freelancers of many states. In this climate, states are able to articulate other interests in the formulation of human rights norms. These may include giving the religious, cultural, or political considerations relevant to the particular state more weight than were previously possible. Alternatively, a state may use that latitude to strike deals with other states in ways that are more consonant with the state's national interests. Either way, less directed and eclectic processes for the formulation of human rights standards are now possible, devoid of the orchestrated plasticity of the past where the big powers struck deals and imposed them on weaker states.

The other view is that the absence of a few "guardian" states leaves the field wide open for governments that have no interest in advancing human rights. This view prefers to see the leadership of a few committed and devoted states, who can promote the human rights agenda. What matters here is not diversity for its own sake, but the elaboration and formulation of standards that will enhance, promote, and protect human dignity, even at the risk of denying a wider global participation. This "eyes-on-the-prize" or "the-end-justifies-the-means" approach is popular with some leading Western international human rights NGOs. While it has its own merits, the argument that human rights standard setting has become more difficult since the end of the Cold War may not be entirely correct. Indeed, it took some eighteen years between the UDHR and the International Covenant on Civil and Political Rights (ICCPR) and the International Covenant on Economic, Social and Cultural Rights (ICESCR), the two principal human

62. Kälin, supra note 42 , at 4 . Others are of the view that the process has not necessarily become more difficult. 
rights treaties ${ }^{63}$; and then it took another ten years for them to obtain enough ratifications to come into force. That was not a particularly rapid process of norm formulation and enactment. Additionally, several other human rights treaties in the period before the 1990s took long periods to negotiate and come into force. ${ }^{64}$

Attempts to create norms and an institution to try international crimes took more than half a century to come to fruition. The reluctance of states to establish an international criminal tribunal straddles the entire Cold War period, and spills over it. Although the idea of the International Criminal Court (ICC) has been on the agenda of the human rights movement since 1948, it was not until 1998 that the Rome Statute on the International Criminal Court was adopted. ${ }^{65}$ The United States stood with Iran, Iraq, Libya, China, Algeria, and Sudan, among others, in its opposition to the ICC. ${ }^{66}$ Most of the close allies of the United States in Europe and elsewhere voted for the ICC. ${ }^{67}$ The eighteen judges elected by the UN to the ICC on 4-7 February 2003 were sworn into office in The Hague on 11 March 2003.

Standard setting and the implementation of human rights have come under new challenges in the wake of the 11 September 2001 suicide attacks in New York City and Washington, D.C. Led by the United States and its avowed "war on terror," many states have qualified sharply their commitment to the promotion and protection of human rights. ${ }^{68}$ Security and the "war on terror" have taken center stage and pushed human rights further down the ladder of international concerns. Since the terror attacks, the United States has enacted and promulgated laws, policies, and measures that

63. International Covenant on Civil and Political Rights, adopted 19 Dec. 1966, G.A. Res. 2200 (XXI), U.N. GAOR, 21 st Sess., Supp. No. 16, U.N. Doc. A6316 (1966), 999 U.N.T.S. 171 (entered into force 23 Mar. 1976) [hereinafter ICCPR]; International Covenant on Economic, Social and Cultural Rights, adopted 19 Dec. 1966, G.A. Res. 2200A (XXI), U.N. GAOR, 21st Sess., Supp. No. 16, U.N. Doc. A6316 (1966), 993 U.N.T.S. 3 (entered into force 3 Jan. 1976) (hereinafter ICESCRI.

64. Convention on the Elimination of All Forms of Discrimination Against Women, adopted 18 Dec. 1979, G.A. Res. 34/180, U.N. GAOR, 34th Sess., Supp. No. 46, U.N. Doc. A/34/46 (1980) (entered into force 3 Sept. 1981), 1249 U.N.T.S. 13, reprinted in 19 I.L.M. 33 (1980) (CEDAW); Convention on the Rights of the Child, adopted 20 Nov. 1989, G.A. Res. 44/25, U.N. GAOR, 44th Sess., Supp. No 49, U.N. Doc. A/44/49 (1989) (entered into force 2 Sept. 1990), reprinted in 28 I.L.M. 1448 (1989); International Convention on the Elimination of All Forms of Racial Disccrimination, adopted 21 Dec. 1965, 660 U.N.T.S. 195 (entered into force 4 Jan. 1969), reprinted in 5 I.L.M. 352 (1966).

65. See Steiner \& Alston, International Human Rights in Context, supra note 18, which states that "the idea of a permanent international criminal court has been part of the agenda of the human rights movement since 1948, when the General Assembly instructed the International Law Commission to study the possibility of establishing one." Rome Statute of the International Criminal Court, U.N. Doc. AVCONF.183/9 (1998). The ICC Statute was adopted by a vote of 120 to seven, with twenty-one abstentions.

66. Kenneth Roth, The Court the US Doesn't Want, N.Y. Rev. Books, 19 Nov. 1998, at 45.

67. The Statute of the ICC came into force on 1 July 2002, when it was ratified by the necessary sixty states.

68. See International. Council on Human Rights Policy, Human Rights after September 11 (2002). 
have contracted civil liberties in the United States. Some of the measures, including the executive order by the Bush administration to establish military tribunals to try individuals designated as terrorists, were more reminiscent of authoritarian and undemocratic states, not the self-proclaimed leader of the free world. ${ }^{69}$ Undemocratic and authoritarian states, which are prone to human rights abuses, have seized on US restriction of civil liberties and disrespect for international law to crush domestic dissent and oppose more openly human rights initiatives at global fora.

This most recent disregard of international law and human rights by the United States has a longer history. The United States qualified its support for universal human rights initiatives almost at the dawn of the human rights movement. Eleanor Roosevelt, the former first lady of the United States, might rightly be described as the mother of the UDHR. However, US enthusiasm waned quickly, and in 1953 the country withdrew from the drafting process of the ICCPR and the ICESCR. ${ }^{70}$ Fearing international scrutiny for racism and other human rights violations-but citing sovereignty concerns--the United States refused to participate in human rights standard setting, let alone the ratification of human rights instruments. It was not until 1992 that the US ratified the ICCPR. Under the Bush administration, US unilateralism in international affairs has become much more affirmed, as demonstrated by the rejection of the Kyoto Protocol, its withdrawal from a number of other international commitments, and the 2003 war on Iraq. ${ }^{71}$

Even so, the current unilateralist approach by the United States is a departure from the more consultative administrations of John F. Kennedy, Jimmy Carter, and Bill Clinton. Kennedy sought to create a more endearing image of the United States abroad through programs such as the Peace Corps and assistance to emergent post-colonial states. Under Carter, human rights rhetoric was given unprecedented prominence in US foreign policy. It was during his administration that a human rights bureau was created in the State Department and a number of measures put in place to include human rights considerations in the calculus of US policy. Foreign assistance and aid were tied to human rights conditions. Clinton revived this more humanist tradition by emphasizing human rights, democracy, and labor rights as important benchmarks of US foreign policy. However, the open defiance-and gratuitous flouting - of international law and human rights by the United States has without doubt weakened the international norm-setting processes and undermined efforts at the enforcement of human rights.

69. Makau Mutua, Terrorism and Human Rights: Power, Culture, and Subordination, 8 Buff. Hum. Ris. L. Rev. 1 (2002).

70. Nigel S. Rodley, On the Necessity of United States Ratification of the International Human Rights-conventions, in U.S. Ratification of Human Rights Treaties: With OR WITHOUT Reservations? 3, 3-4 (Richard B. Lillich ed., 1981).

71. Kyoto Protocol to the UN Framework Convention on Climate Change, U.N. Doc. FCCC/CP/1997/7/Add.2 (10 Dec. 1997). 


\section{Traditional Obstacles to Standard Setting}

The most widely used instruments for the creation of human rights standards are treaties and declarations. Usually, these devices for the promotion or protection of human rights were negotiated under the auspices of the UN Commission on Human Rights. The treaty - more than the declaration-has been the primary instrument for the regulation and stabilization of relationships between and among states. The treaty, much like customary law, which takes longer to coalesce into a binding obligation, creates legal norms among states. The treaty then is a contract whose core is the maxim pacta sunt servanda. That maxim is an ironclad understanding that commitments, which are undertaken by states voluntarily, publicly, and formally must be honored. ${ }^{72}$ That is why treaties are regarded as the most effective tools for the development of norms and for the protection of the interests of states, their nationals, and ideals such as human rights.

Treaty making is at its core a state-centered process, even if the initiative and drive come from the NGO sector. The negotiating, drafting, adopting, or ratifying stages all present each state with a chance to influence the shape and timing of the final product. A treaty, for example, can pass through all the stages up to adoption but still fail to come into force if it does not garner the necessary ratifications. That had been the fate of the 1990 Convention on the Rights of Migrant Workers and Their Families before July 2003, when it finally came into force after receiving twenty-seven ratifications. ${ }^{73}$ The long arduous road faced by this convention is but one sign that states may be more reluctant now to accept new human rights treaties. Similarly, a 1995 amendment to the Convention on the Elimination of All Forms of Discrimination against Women (CEDAW),$^{74}$ which would have allowed the Committee on the Elimination of Discrimination against Women, the treaty body, to meet more often and for a longer period, remained without the necessary ratifications. As of February 2007, the amendment had only gained forty-eight acceptances out of the 185 states parties to CEDAW, far short of the two-thirds required for its entry into force. ${ }^{75}$

72. Vienna Convention on the Law of Treaties, U.N. Doc. AVCONF.39/27 (1969), 1155 U.N.T.S. 331, (entered into force 27 Jan. 1980), reprinted in 8 I.L.M. 679 (1969). Article 26, which is entitled Pacta Sunt Servanda, provides that "[e]very treaty in force is binding upon the parties to it and must be performed in good faith."

73. International Convention on the Protection of the Rights of All Migrant Workers and Their Families, adopted 18 Dec. 1990, art. 76, I 2, G. A. Res. 45/158, U.N. GAOR, 45th Sess., U.N. Doc. AVRES/45/158 (1990).

74. CEDAW, supra note 64 .

75. Report of the States Parties to the Convention on the Elimination of All Forms of Discrimination against Women, U.N. Doc. CEDAW/SP/1995/2 (1995); Amendment to Article 20. Paragraph 1, of the Convention on the Elimination of All Forms of Discrimination against Women, adopted 22 Dec. 1995, G.A. Res 50/202, U.N. GAOR, 50th Sess., U.N. Doc. A/RES/50/202 (1996). As of 28 February 2007 only forty-eight of the 185 states 
Denying ratification is traditionally an effective strategy to cripple a human rights instrument. Procrastination, procedural delays, and artificiallyprolonged negotiations over the drafting of a treaty or declaration constitute an array of other options that allow states to resist and scuttle the creation or enforcement of human rights norms. The complicated and politicized process through which the Draft Optional Protocol to the Convention against Torture and Other Cruel, Inhuman or Degrading Treatment or Punishment $(C A T)^{76}$ underwent is a testament to these maneuvers. Although negotiations on the Draft Protocol commenced in 1992, it was not until 2002-a decade later-that it was adopted by majority vote. On 7 November 2002, the Optional Protocol to CAT was approved by 104 states. ${ }^{77}$ The Protocol came into effect on 22 June 2006 after twenty ratifications. ${ }^{78}$ It does not accept reservations. ${ }^{79}$

Many states opposed the Optional Protocol because they perceived it as being too intrusive on their sovereignty, although some states, like the United States, knowingly but falsely claimed that it would be too expensive to implement. ${ }^{80}$ Most, like China, based their opposition on formal sovereignty arguments. ${ }^{81}$ To be fair, the Optional Protocol is a very intrusive document. It creates a global system for the mandatory inspection of detention facilities ${ }^{82}$ and requires states to set up domestic, national preventive mechanisms. ${ }^{83}$ The domestic mechanisms are independent visiting bodies, whose purpose is to physically monitor places of detention. Both the global and domestic mechanisms are designed to prevent torture and ill treatment of detainees.

There are other, equally effective, strategies for obstruction. A state could simply refuse to participate in the norm creation process, or it could block consensus and create a variety of obstacles and employ any number of delaying techniques along the way, making it difficult for the process to get through the drafting stage. If all these maneuvers fail, the state could withhold ratification and lobby other states to do the same, denying the instrument

parties to CEDAW had accepted the amendment to Article 20, Paragraph 1, well short of the two-thirds required for its entry into force. See http://www.un.org/womenwatch/ daw/csw/csw51/statements/DS_Statement_introduction_final.pdf.

76. Draft Optional Protocol to the Convention against Torture and Other Cruel, Inhuman or Degrading Treatment or Punishment, U.N. ESCOR, Comm'n on Hum. Rts.; 58th Sess., U.N. Doc. E/CN.4/2002NG.11/CRP.1 (2002).

77. Interview with Emma Carmen-Guevas, Office of the High Commissioner for Human Rights, Geneva, Switzerland (6 Dec. 2002).

78. Optional Protocol to the Convention against Torture and other Cruel, Inhuman or Degrading Treatment or Punishment, adopted 18 Dec. 2002, G.A. Res. 57/199, U.N. GAOR, 57th Sess., art. 28, U.N. Doc. A/RES/57/199 (2003).

79. Id. art. 30.

80. Interview with Carmen-Guevas, supra note 77.

81. Id.

82. Optional Protocol, supra note 78, arts. 1, 2.

83. Id. arts. 3, 4. 
the requisite number of ratifications to come into force. If all these routes turn out to be fruitless or prove costly to the state, it could ratify the treaty but with a bevy of reservations. Reservations are a double-edged sword. They can be genuine vehicles allowing a state to accept a treaty without compromising an important interest or norm. Reservations can also be used facetiously by states intent on hollowing out the treaty.

Given the multiplicity of states at the United Nations-from fifty-six in 1948 to 191 today - treaties have to accommodate the interests of a much more diverse group of players. It is this difficulty of finding common ground that makes reservations an important escape valve if treaties are to find acceptance in a gallery of divided and competing cultural, political, and historical values. It is conceivable that without the device of reservations many a treaty would not have seen the light of day. Reservations have also become so commonplace, particularly in the human rights field, that they threaten the integrity of the commitments negotiated by states and undertaken by them.

It is the view of some in the human rights movement that reservations-some of great significance-make nonsense of treaty ratification and its entry into force. The Vienna Convention on the Law of treaties defines a reservation as any "unilateral statement, however phrased or named, made by a state, when signing, ratifying, accepting, approving or acceding to a treaty, whereby it purports to exclude or to modify the legal effect of certain provisions of the treaty in their application to that state. ${ }^{\prime \prime 4}$ This broad provision gives the false impression that a state can express reservations to a treaty at virtually any stage after its adoption. However, the Vienna Convention forbids states to formulate any reservations which are "prohibited by the treaty" and which are "incompatible with the object and purpose of the treaty. ${ }^{\prime 85}$ Thus, a reservation is any unilateral statement made by a state when signing or adhering to an international agreement-whatever that statement is termed - if it purports to exclude, limit, alter, modify, or change, in any way, the state's obligations under that instrument. ${ }^{86}$

The International Court of Justice stated in 1951 in an advisory opinion on the Genocide Convention that states are free to make reservations

84. Vienna Convention on the Law of Treaties, supra note 72 , art. 2(1)(d).

85. Id. art. 19 provides that:

A State may, when signing, ratifying, accepting, approving or acceding to a treaty, formulate a reservation unless:

(a) the reservation is prohibited by the treaty;

(b) the treaty provides that only specified reservations, which do not include the reservation in question, may be made; or

(c) in cases not falling under sub-paragraphs (a) and (b), the reservation is incompatible with the object and purpose of the treaty.

86. Restatement (Third), Foreign Relations Law of the United States $§ 313$ (1987). 
but that others are also free to object to them. ${ }^{87}$ The key question, the $1 \mathrm{CJ}$ stated, was "the compatibility of a reservation with the object and purpose of the Convention that must furnish the criterion for the attitude of a state in making the reservation on accession as well as for the appraisal by a state in objecting to the reservation. ${ }^{\prime 88}$ Stated otherwise, a reservation would not nullify a state's membership to a treaty even if objected to by another state so long as that reservation is compatible with the object and purpose of the treaty. A state that objects to another's reservation can consider the reserving state not a party to the treaty if it deems the reservation incompatible with the object and purpose of the treaty. This opinion exemplifies the difficulties of sorting out conflicts relating to reservations. It also points to the complexity of the treaty as a standard setting tool and underlines the fact that a treaty is not the certain, problem-free vehicle that some human rights advocates think it to be.

Reservations are now a common feature of human rights treaties. The highest number of reservations have been entered against the Convention on the Elimination of Discrimination against Women (CEDAW), which has become a notorious feature of that historic women's rights document. Whether a treaty expressly prohibits reservations that are incompatible with its "object and purpose," as CEDAW does, is of little consequence. ${ }^{89}$ The ICCPR, which is silent on the issue, has more than its share of troubling reservations. In sum, reservations are viewed permissively and are tolerated widely. There is a reluctance to declare any reservation invalid because of the perceived need for treaties to attract the highest number of adherents.

The reservations against CEDAW are the clearest sign yet of the need to rethink the view that treaties ought to be the preferred method for standard setting in human rights. Many of the reservations to CEDAW go to its fundamental provisions, the ones that concern the "object and purpose" of the treaty. Reservations to Article 2-a blanket condemnation of discrimination against women and an ironclad obligation on the state to immediately eliminate such discrimination-are regarded as particularly odious and incompatible with the object and purpose of CEDAW. It cannot be permissible to oust the provision on non-discrimination in a treaty whose central purpose is to eliminate discrimination. Yet that is precisely what many states have done with CEDAW. Commentaries by scholars and the work of human rights advocates have not produced any demonstrable effect on the states bent on circumventing their obligations under CEDAW through reservations. At the very least, the CEDAW experience should suggest a

87. Reservations to the Convention on Prevention and Punishment of Crime of Genocide, Advisory Opinion, 1951 I.C.J. 15 (28 May 1951).

88. Id.

89. CEDAW, supra note 64 , art. $28(2)$. 
more tempered approach to treaties as the avenue of choice for standard setting in human rights.

\section{E. Politics as Obstruction}

States do not want to be seen to oppose human rights merely to retain power. Usually, objections to particular human rights standards are couched in arguments about sovereignty, self-determination, the need for development, and the struggle against foreign domination or imperialism. Human rights are a noble ideal, and the only way to credibly confront it-without appearing negative-is by putting it up against another equally noble ideal. It is this public relations game that has turned the human rights crusade into a sport of organized politics within the corridors of the United Nations. Opposition to human rights standard-setting processes is almost never presented as a frontal attack on human rights. This applies in equal measure to all states, whether they are Western, Latin American, African, or Asian and whether they hold themselves out as the guardians of human rights or not. One must always peel the layers of argument to appreciate the genuine reasons behind a state's reluctance to submit to particular human rights standards. It is because of these nuances that advocates for new standards in human rights must become more creative.

States often accede to or ratify human rights instruments knowing that they do not intend, and may not have the capacity or resources, to implement them. The Democratic Republic of Congo, formerly Zaire under the late Mobutu Sese Seko, itched to ratify every human rights instrument it could get its hands on. ${ }^{90}$ However, Zaire was one of the most egregious human rights violators and only honored its treaty obligations in the breach. ${ }^{91}$ Adopting a trigger-happy approach to treaty ratification, many states have no problem buying into a fashionable discourse without the slightest intention of carrying out their obligations under human rights instruments. They view the universal mechanisms and institutions for the elaboration and enforcement of human rights as impotent and, therefore, posing no real threat to either the political elite in power or to state sovereignty. To such states, there are no real costs to joining. In these cases, a different approach at norm creation and standard implementation is required. Ratification of treaties means little where the state has no political will or interest in their domestic application and implementation.

90. See generally Makau Mutua \& Peter Rosenblum, Zaire: Repression as Policy, A Human Richts RePORT 37 (Michael Posner \& William O'Neill eds., 1990).

91. See id. 
In some cases, states will pay lip service to certain standards but take no steps to advance or consolidate them. A case in point is the much-maligned right to development. There is universal consensus that development is an essential, if not indispensable, condition of humanity. Despite this, there is surprisingly no agreement amongst states, international institutions, and NGOs on what constitutes development let alone how it should be brought about. Some think of development as economic; something to be measured in the numbers of the gross domestic product. Others think of it as advances in culture, political organization, or military achievement. Amartya Sen has written about development as the complex combination and interaction of instrumental freedoms - political freedoms, economic facilities, social opportunities, transparency guarantees, and protective security. ${ }^{92}$ As he notes:

These instrumental freedoms tend to contribute to the general capability of a person to live more freely, but they also serve to complement one another. While development analysis must, on the one hand, be concerned with the objectives and aims that make these instrumental freedoms consequentially important, it must also take note of these empirical linkages that tie the distinct types of freedom together, strengthening their joint importance... . The claim that freedom is not only the primary object of development but also its principal means relates particularly to these linkages. ${ }^{93}$

Political elites, in both the North and South, talk about the importance of development but neither has the will and vision to bring it about. That is why UN bodies concerned with the right to development have been unable to develop a cogent jurisprudence and a universally acceptable formula or blueprint for implementing it. ${ }^{94}$ The murky status of the right to development has ensured that it is not likely to be encoded in a binding treaty any time soon. In the meantime, NGOs, states in the South, and UN bodies must redouble their efforts to flesh out the standards and other benchmarks for this important right so the paths to its implementation can become clearer and more persuasive to the interests of states in the North and the multilateral development and financial institutions they control. The elaboration of the right is pursued more fruitfully within the Committee on Economic, Social and Cultural Rights, within the UN Human Rights Council, and by the independent expert on the right to development.

92. Amartya Sen, Development as Freedom 38 (1999).

93. Id.

94. Georges Abi-Saab, The Legal Formulation of the Right to Development, in THE RIGHT to Development at the International Level 159, 163 (René-Jean Dupuy ed., 1980). 


\section{F. The Ownership of Norms and Standards}

In social terms, there are no natural universal norms or standards. As correctly noted by Abdullahi An-Na'im, all norms are founded on specific cultures and philosophies. ${ }^{95}$ Adamantia Pollis and Peter Schwab have asserted that "the Western political philosophy upon which the Charter [UN] and the Declaration [UDHR] are based provides only one interpretation of human rights, and this Western notion may not be successfully applicable to nonWestern areas for several reasons. ${ }^{\prime 96}$ In the United States, human rights are generally regarded "as designed to improve the condition of human rights in countries other than the United States (and a few like-minded liberal states)." ${ }^{\prime 97}$ Despite this early foundation in Eurocentrism, human rights norms have at least gained rhetorical acceptance in virtually every state.

Since 1945, the circle of actors in the human rights movement has expanded rapidly. The post-1945 norms of the human rights movement drew from a variety of struggles, including those against colonialism, slavery, racism, religious intolerance, discrimination of women, and suppression and exploitation of workers, among others. It was not, however, the leaders or the victims of these struggles who sat at the high councils to craft the human rights corpus. At its inception, particularly during the formulation of the UDHR, the codification of human rights norms was the work of two key actors. The most important group of actors was the cluster of Western and European states around the United States, the victorious allies, who dominated the United Nations. It was their concept of human rights, as noted by Cassese, that was imposed on the world. ${ }^{98}$

The other important voices were those of non-state actors drawn largely from Western civil society organizations, the International Committee of the Red Cross, Jewish, Christian, and women's organizations; and professional and trade union organizations. ${ }^{99}$ Some of these groups, including the American Anthropological Association, submitted either memoranda or their own draft versions of the UDHR to the UN Commission on Human Rights. ${ }^{100}$ There were virtually no Southern, non-state actors at this stage. In addition, both the state and non-state actors can hardly be said to have been diversely inclusive of most peoples, cultures, and traditions. Today, the UDHR is cited with near-universal approval, although, as noted, as a document of norms

\footnotetext{
95. An-Na'im, supra note 23.

96. Adamantia Pollis \& Peter Schwab, Human Rights: A Western Construct with Limited Applicability, in Human Richts: Cultural and Ideological. Perspectives 1 (Adamantia Pollis \& Peter Schwab eds., 1979).

97. Louis Henkin, The Ace of Rights 74 (1990).

98. Cassese, supra note 19.

99. MORSINK, supra note 28 , at 9 .

100. Id. at ix, 9 .
} 
it was at its launch owned by a narrow and select group of actors. The nations that drafted the UDHR directly colonized three quarters of the earth and enforced brutal, racist, and even genocidal policies in many places. The few Southern states present in the standard setting process-such as India, Lebanon, Burma, Pakistan, the Philippines, Ceylon, and Syria-had recently gained independence and joined the UN between 1946-1948. As one analyst puts it:

In 1914, Lenin calculated that "more than half of the world's population lived in colonies, which covered 3/4 of the world's territory," a calculation that was still roughly correct at the end of the 1940s. This fits the estimate Philippe De La Chapelle made of the United Nations membership at the time the Declaration was adopted: "North and South America with 21 countries represented $36 \%$ of the total, Europe with 16 countries $27 \%$, Asia with 14 countries $24 \%$, Africa with 4 countries a mere $6 \%$, and the South Sea Islands with three countries $5 \%$." This shows that the continents of Africa and Asia were grossly under-represented. And this is where in the 1940s most of the most prominent drafting nations still had their colonial empires. ${ }^{101}$

However, the changes in the character of international community are reflected in the human rights instruments and standards that the UN has adopted since the $1960 \mathrm{~s}$. The UDHR and the ICCPR, which in practice have been regarded as the most important human rights documents, are characterized by their emphasis on individual rights, perhaps the most essential element of the rule of law in a Western liberal democratic state. The ICESCR, which is ratified by roughly the same number of states as the ICCPR, is much maligned and regarded by many as the "other" covenant. Many states, particularly in the West, have interpreted its focus on economic and social justice as a threat to free market values. Socialism and the Latin American and Caribbean states heavily influenced the ICESCR. Even the ICCPR, which regards the individual as the center of the moral universe, nods at collective or groups rights twice. The provisions on the right to selfdetermination of peoples ${ }^{102}$ and on the integrity and survival of cultures ${ }^{103}$ are a departure from the focus on individual rights.

Emergent states in the global South have exerted some influence on this debate. They are responsible primarily for the deviation from the cultural individualism of the West. Such deviation is attributed to the influence of the newly independent states in the UN standard setting fora from the 1950 s onward. Most non-European cultures tip the balance in favor of the community rather than the individual. There is a tendency to emphasize group and collective rights, sometimes to the detriment of the individual,

101. Id. at 96.

102. ICCPR, supra note 63 , art. 1 .

103. Id. art. 27. 
in societies outside the European world. The African Charter on Human and Peoples' Rights, the regional human rights system for the continent, captures this emphasis well. ${ }^{104}$ The African Charter creates the so-called three generations of rights: civil and political rights; economic, social, and cultural rights; and people's rights, such as the rights to development, ${ }^{105}$ peace, ${ }^{106}$ and a satisfactory environment. ${ }^{107}$ The Charter also departs from the script of other human rights instruments and imposes duties on individuals. ${ }^{108}$ Such duties are owed to other individuals, the family, society, and the state. In Asia, the lines between the individual, the society, and the state are blurred similarly by conceptions of duty. ${ }^{109}$ Although an oversimplification of both positions, there is a consensus that non-European cultures seek more balance between the individual and the society than their European counterparts.

The tendency of societies in the South to highlight the community and collective rights conceptions is underscored by the normative preferences of many of the human rights instruments that have been adopted since the 1960s. After the covenants, a term generally understood to refer only to the ICCPR and the ICESCR, several other instruments on different human rights themes were adopted. These included the 1965 International Convention on the Elimination of all Forms of Racial Discrimination, the 1976 International Convention on the Suppression and the Punishment of the Crime of Apartheid, CEDAW in 1981, the 1986 Declaration on the Right to Development, and the 1990 Convention on the Rights of the Child. These latter-day instruments are progressively more detailed and either address matters left out by the UDHR, ICCPR, and the ICESCR, or further elaborate on them. The instruments move away from the focus on individualism and tackle issues affecting groups and group rights or systemic and deeply embedded social and economic problems that require radical solutions. Efforts to set standards on the disabled, ${ }^{110}$ indigenous peoples, and women respond to concerns that go beyond the individualist focus of the earlier human rights instruments.

104. African Charter on Human and Peoples' Rights, adopted 27 June 1981, O.A.U. Doc. CAB/ LEG/67/3//Rev.5 (entered in force 21 Oct. 1986), reprinted in 21 I.L.M. 58 (1982).

105. Id. art. 21.

106. Id. art. 23.

107. Id. art. 24.

108. Id. arts. 27-29. See Makau Mutua, The Banjul Charter and the African Cultural Fingerprint: An Evaluation of the Language of Duties, 35 VA. J. INT'L L. 339 (1995).

109. Bilahari Kausikan, Asia's Different Standard, Foreicn Poucr 24 (1993), at 24. See Yash Ghai, Human Rights and Governance: the Asia Debate, 15 Aust. Y.B. INT'L L. 1 (1994) for a critique of the proponents of distinctive Asian cultural outlooks.

110. Since 2001, when President Vicente Fox of Mexico called for a UN convention on disabilities, pressure has mounted for a treaty. See John R. Mathiason, Considerations for the Proposed International Convention to Promote and Protect the Rights and Dignity of Persons with Disabilities, WorıdEnable (2002), available at http://www.worldenable. net/mexico2002/considerations.htm. 


\section{G. Constituencies and Ownership}

Human rights norms and standards respond to specific and real violations. They seek to address the plight of victims. Human rights standards cannot be developed and lobbied for unless there is an identifiable, usually sympathetic, victim. The norm must also identify the villain, either as the state itself, or some other instrumentality acting as a proxy for the state. It could also be an individual, group, or an entity perpetrating the violation with the tacit approval and support of the state. In other cases, the state may be unwilling or unable to stop the victimizer but is still accountable for the abuse. The important thing is that there be a nexus between the state and the abuse committed. This nexus is necessary because the state is the basic obligor of the human rights corpus. It is the target of human rights standards. This means that either the victims become advocates of their own cause or others take up their plight. The plight must be made visible and manifest for standards on promotion, assistance, and protection to be created.

Paradoxically, the victims rarely own the standards relevant to their plight. This is because standard setting in human rights is an elite-driven and not victim-centered process. It is state-not people-centered. ${ }^{11}$ Standards are also set far away from the killing fields. The normal setting is a UN conference room where diplomats and non-state actors of means mingle and debate over the nuances of law making. Rarely, if ever, are the victims in sight, although sometimes they are paraded for effect. Generally, ownership of standards remain with those who agitate for them and work to police their development and enforcement. Thus, although victims may know their rights-and in some cases may even know the mechanisms for influencing or vindicating them-the definition of their suffering usually rests with a faceless bureaucrat or an opaque committee somewhere in Geneva or New York. Each human rights standard or norm therefore has a constituency or constituencies of owners. There are, however, some notable exceptions. The Declaration on Human Rights Defenders is unique because it directly affects the most engaged community in the human rights movement. The Declaration could even be self-serving if not for the incredible brutalities visited on human rights advocates across the world. The Declaration was initiated and advocated for by the NGO human rights community. The International Service for Human Rights, ${ }^{12}$ in particular, was instrumental in its realization. ${ }^{13}$

111. Interview with Mary Robinson, former United Nations High Commissioner for Human Rights, New York (28 Nov. 2002).

112. The Geneva-based International Service for Human Rights is an international association serving human rights defenders.

113. Interview with Joe Oloka-Onyango, Member, UN Sub-Commission on the Promotion and Protection of Human Rights, and Rapporteur on Globalization, New York (1 Dec. 2002). 
There is a marked difference in the energies and resources that are expended on various standards. The question of constituencies and ownership speaks volumes about how much effort and money are put into fighting for different norms. Witness the difference between the resources expended on the Declaration on the Right to Development and the Protocol to the Torture Convention or even the Declaration on Human Rights Defenders. Certain constituencies enjoy a privileged position in the world of standard setting. Their effective organizational skills, adequate funding, credible reputations, and access to powerful and sympathetic states make them formidable. Their access to renown scholars, familiarity with the United Nations, knowledge of international politics and lobbying, and trusted contacts within powerful international media organizations give them a lot of power and clout. Not to be underestimated is the fact that the key UN offices are located in New York and Geneva, which to many of these groups is familiar cultural and political territory.

Well-organized constituencies conduct most of their activities outside the corridors of the United Nations. In the cases of the Declaration on Human Rights Defenders and the Draft Optional Protocol to CAT, a lot of the necessary work was done by NGOs outside the corridors of the United Nations. However, the mobilization of such a powerful array of players is only possible where a constituency has an elite base. This requires funding, an influential NGO or a credible umbrella body, a cadre of good scholars, and seasoned activists-attributes that individuals, NGOs, or groups from the South are not likely to command readily. Such a gap can only be breached if groups in the South team up with groups in the North to work towards a common goal. This requires that groups in the North feel invested in those standards that motivate, drive, and interest groups in the South. One way to reduce the asymmetry of power between the North and the South, and to make sure that the human rights agenda is not only driven by interests from the West, is through the cultivation of humility by groups from the privileged parts of the world. The energy and resources that NGOs in the West put into the campaign for the Declaration on Human Rights Defenders illustrates this point. NGOs in the North pushed zealously for that instrument because their interests and those of their counterparts in the South converged rather perfectly. Clearly, NGOs in the North are not the major targets of repression by states in the South, where the work of human rights advocacy has historically been perilous.

Human rights work by NGOs in the South usually entails risks to life and limb. Even so, it was Western NGOs that pushed the hardest for the Declaration on Human Rights Defenders. One of the obvious reasons for Western leadership on this issue was its access to global power structures and availability of resources for advocacy. It was not that NGOs in the South are not interested in their own protection; but rather that wanting a 
standard and being able to effectively push for it are two different things. There is a distinction between those who need norms and those who are able to lobby effectively for their formulation. Western NGOs were instrumental in securing Norway as the lead state on the Declaration on Human Rights Defenders. Most European states heavily favored the Declaration, while the United States refrained from opposing it. African states did not oppose openly the Declaration because there had been NGO pressure on the African Commission on Human and Peoples' Rights to establish a human rights defenders unit. ${ }^{114}$ The inter-American human rights system already established a unit for the promotion and protection of the rights of human rights defenders. ${ }^{115}$

There is a global interest in protecting the rights of human rights workers. The Declaration protects NGOs in the South from strangulation by the state and provides them with operational space and freedom from the state to conduct their advocacy. Importantly, it allows them to solicit and receive funds and resources from any source to support their work. ${ }^{116}$ This is an important victory because states in the South feel that they often have to compete with NGOs for Western donor funding. Some states have tried to control, limit, and even prevent NGOs from directly receiving donor funding, without which they would most likely wither away, collapse, or become completely ineffective. ${ }^{117}$ For Western NGOs-many of whom exist primarily to monitor, expose, and limit human rights violations in Southern states - the Declaration further extends their reach because it creates a borderless universe for advocacy. It effectively abolishes, for operational purposes, the distinction between domestic and international human rights NGOs and accords them virtually the same protections from the national state. This means that international human rights NGOs, like Amnesty International, enjoy substantially the same freedoms that the Kenya Human Rights

114. See World Organization against Torture (OMCT), Intervention of the Observatory on the Situation of Human Rights Defenders Before the African Commission on Human and Peoples' Rights (2002), available at http://www.omct.org\%2Findex.php\%3Fid\%3DOB S\%26lang\%3Deng\%26actualPageNumber\%3D2\%26articleSet\%3DEvents\%26articleld \%3D2548\%26PHPSESSID\%3D71dfbab0d152b21b2db76b5ed0ddfb57.

115. Sidiki Kaba \& Eric Sottas, To Defend Human Rights: A High Risk, The Perspective (25 Mar. 2002), available at http://www.theperspective.org; Human Rights Defenders in the Americas: Support for the Individuals, Groups, and Organizations of Civil Society Working to Promote and Protect Human Rights in the Americas, adopted 5 June 2001, O.A.S. Doc. AG/RES.1818 (XXXI-O/01) (2001).

116. Declaration on Human Rights Defenders, supra note 50, art. 13. It provides, in part, that "everyone has the right, individually and in association with others, to solicit, receive and utilize resources for the express purpose of promoting and protecting human rights and fundamental freedoms through peaceful means."

117. See Human Rights Watch, Human Rights Watch Worlo Report 2000, at 15-17 (2000) for restrictive measures taken by African states against human rights NGOs. 
Commission, a domestic NGO, is entitled to in its work on Kenya. ${ }^{118}$ That is why the Declaration was a perfect convergence of the interests of NGOs in both the North and the South. Coalitionary energies are constructed easily around such shared and mutually beneficial standards, a fact that makes their passage by states less difficult.

The contrasting fates suffered by the Declaration on Human Rights Defenders and the Declaration on the Right to Development indicate the importance of the ownership of standards. Who wants a standard, cares for it, and is able to fight for it makes all the difference. The woes of the right of development underscore the difficulties that can bedevil a standard when it lacks a solid coalition of able, determined, and influential constituencies. There is inherent bias - for and against - certain standards by various actors in the human rights movement and in the standard-setting fora in general. As Joe Oloka-Onyango points out, relativism pervades the entire norm making and standard-setting processes at the United Nations. ${ }^{119}$ What he calls "empirical relativism" leads to more energy being applied towards the Optional Protocol to CAT or the Declaration on Human Rights Defenders than on the right to development. ${ }^{120}$ This is a problem which is traced to how the human rights agenda is set: Why is a certain matter important, who thinks it is important, and why.

Debates on the right to development have dichotomized the world. Whatever interest there is in the right to development in some parts of the world, it is often built on free market policies whose implementation is viewed by others as deepening its plight. Lacking any independence on economic matters and woven tightly into the global economy, poor states cannot challenge effectively the hegemony of rich states. Lamentably, many poor states do not have the focus, the will, and the expertise to argue their positions within standard setting fora. On such deliberations within the UN, Oloka-Onyango points out that the "South is not well prepared for these debates; it is happy with the high rhetoric of the debate, but it is not prepared for the nitty-gritty of the issues, like the scope of the obligations imposed by norms and their details."121 While the disinterest of the South leaves a vacuum, it is compounded by the preponderance of NGOs from the South who lack the skill and resources to advance the agenda of the right to development. Regrettably, NGOs from wealthy countries-whose

118. Declaration on Human Rights Defenders, supra note 50, art. $9(3)(b)$, gives everyone, including associations, the right to observe trials to assess whether they meet international legal obligations. Article 9(3)(c) permits anyone or organization the right to offer and provide legal advice and representation. States have in the past severely restricted both rights.

119. Interview, Oloka-Onyango, supra note 113.

120. Id.

121. Id. 
interest and clout could make a difference-have not taken a lead in the fight for the right to development.

Finally, the struggles and processes for the realization of the Guiding Principles on Internal Displacement and the Optional Protocol on the Torture Convention tell a somewhat different but familiar story. Francis Deng, the former Sudanese diplomat and government minister, was by temperament and origin the ideal choice for appointment as the Special Representative of the UN Secretary General on Internally Displaced Persons. His native Sudan is home to an estimated 4.4 million IDPs, the most of any state. ${ }^{122}$ Only Angola, with 4.1 million IDPs, comes close. ${ }^{123}$ Although not an IDP himself, Deng cannot but be concerned personally by the issue. This is the one case where the standard-setter is an indirect victim, someone who understands and appreciates naturally the magnitude of the problem and the plight of IDPs. As put by Bacre Waly Ndiaye, Director of the UN Office of the High Commissioner for Human Rights in New York, the "Guiding Principles were primarily the work of one individual, the Special Representative."124

Working with several legal and other experts-among them Walter Kälin of the University of Bern and Roberta Cohen, a prominent advocate on behalf of refugees and IDPs_Deng and his colleagues decided on the novel approach of developing Guiding Principles instead of taking the resistance-prone route of seeking a convention, a resolution, or a declaration. Secondly, Deng was able to assemble a team of respected experts. This lent the work credibility and access to influential governments and offices across the world. Lastly, Deng used his skill as a diplomat to convince reluctant states that the Guiding Principles were not a new imposition on states but a simple restatement in one document of existing legal obligations.

States, intergovernmental institutions, and NCOs have come to regard the Guiding Principles, which achieved success and acceptance within a short time, positively. The Guiding Principles started a flurry of activity, especially training workshops for government officials, relief agencies, and workers concerned with the care and welfare of IDPs. As a result, many disciples now claim ownership of the Guiding Principles. To be certain, valid concerns had been expressed that sufficient international legal rules already exist in this area, and the creation of new rules risked undermining existing law. The International Committee of the Red Cross (ICRC), in particular, has repeatedly underlined the necessity of a nuanced approach, given that in most humanitarian crisis situations, including those involving

122. Francis Deng, The Global Challenge of Internal Displacement, 5 WASH. UNIV. J. L. \& Poucr 141, 142 (2001). See also Norwegian Refucee Council, supra note 33, at 75.

123. Norwegian Refucee Council, supra note 33 , at 32.

124. Interview with Bacre Waly Ndiaye, Director, UN Office of the High Commissioner for Human Rights, New York (2 Dec. 2002). 
internal displacement, the problem is more an intentional disregard for the rules than a lack of rules as such. ${ }^{125}$

In these circumstances, it is important to recall that the Guiding Principles were intended to reaffirm and clarify the most important rules of protection in the field of human rights and humanitarian law, and first and foremost, the relevant binding law should be invoked as the basis for the Principles (such as the detailed provisions of international humanitarian law in situations of armed conflict). At the same time, scholars affirm that the "sum" of the Guiding Principles is "greater than its parts," that is, they "have effectively made maximum use of international human rights and humanitarian law, and the end product provides more comprehensive protection of IDPs and more concrete guidance than each individual instrument alone."126 Ultimately, the success of the Guiding Principles is attributable to a legitimate appointee, who adopted the appropriate strategy and mobilized a committed group of experts as the constituency for developing and advocating those rights.

The Optional Protocol to the Torture Convention traveled a different road from the Guiding Principles on IDPs. It, too, was realized ultimately because its constituencies were equally committed, focused, and influential. The Optional Protocol to CAT was initially the idea of Swiss intellectuals, not a project conceived in the South. The 1987 European Convention inspired the notion of an Optional Protocol for the Prevention of Torture and Inhuman or Degrading Treatment or Punishment (ECPT). ${ }^{127}$ The ECPT is an improvement over the 1984 UN Convention against Torture and Other Cruel, Inhuman or Degrading Treatment or Punishment ${ }^{128}$ because it emphasizes prevention and adopts a more innovative and intrusive supervision regime. ${ }^{129}$ Europeans

125. Interview with Stephanie Kleine-Alhbrandt, Human Rights Officer, Office of the High Commissioner for Human Rights, Geneva (6 Dec. 2002); Jean-Philippe Lavoyer, forced Displacement: The Relevance of International Humanitarian Law, in HumAN Rights AND Forced Displacement 50 (Anne F. Bayefsky \& Joan Fitzpatrick eds., 2000); Jean-Phillipe Lavoyer, Guiding Principles on Internal Displacement, 38 INT'L Rev. Red CROss 467 (1998); Robert K. Goldman, Codification of International Rules on Internally Displaced Persons, 38 InT'L Rev. Red Cross 463 (1998).

126. Bjorn Pettersson, International Human Rights and Humanitarian Law Merged into One Operational Instrument: The UN Guiding Principles on Internal Displacement (2002), available at http://www.internal-displacement.org/8025708F004BE3B1/(httplnfoFiles)/ 9E0C35D088DFA96280257090004E198E/\$file/Complementarity_\%20of_HR_and_IHLGP.pdf.

127. European Convention for the Prevention of Torture and Inhuman or Degrading Treatment or Punishment, Europ. T. S. 126, (entered into force 1 Feb. 1989).

128. Convention Against Torture and Other Cruel, Inhuman or Degrading Treatment or Punishment, adopted 10 Dec. 1984, G.A. Res. 39/46, U.N. GAOR, 39th Sess., Supp. No. 51, at 197, U.N. Doc. A/39/51 (1985) (entered into force 26 June 1987), reprinted in 23 I.L.M. 1027 (1984), substantive changes noted in 24 I.L.M. 535 (1985).

129. Malcolm D. Evans \& Rod Morgan, Preventing Torture: A Study of the European Convention for the Prevention of Toriure and Inhuman or Degrading Treatment or Punishment 191-93 (1998); see also BUERGENTHAL, Et AL., supra note 6, at 191-93. 
did not think they needed the Torture Convention, but they wanted a more effective instrument to set an example for the rest of the world. As it has turned out, a number of European states have been found in violation of their own Torture Convention. ${ }^{130}$

Swiss intellectuals and the Association for the Prevention of Torture quickly recruited Costa Rica to co-sponsor and push for the Optional Protocol to CAT. ${ }^{131}$ It was important that the initiative have the backing from the South, so it would have a global character. This was also necessary because the South was the target of the Optional Protocol. When the Association for the Prevention of Torture prepared the first draft of the Optional Protocol, it became clear at a later stage in the drafting process that European states and Latin American states, including Mexico, were also supportive of the Optional Protocol. Most opposition came from the United States, Russia, China, India, the Middle East and some African states. The strategy employed in the formulation of the Optional Protocol sought to be geographically inclusive with a particular emphasis on ownership and participation by governments and civil society organizations from the South. ${ }^{132}$ The vote tallying the 104 states that adopted the Optional Protocol underlined this broad, geographic support for an initiative that had started out as a European project. The lesson from the adoption of the Optional Protocol to CAT is that clever and serious strategies and broad coalition building can lead to a wide acceptance of a standard, no matter its place of origin.

What is clear is that human rights standards cannot be developed or realized unless constituencies for them exist, or until sympathetic, vocal, knowledgeable, and supportive thinkers and advocates join the campaign for them. Standards will only be successful in their various stages-from formulation to implementation - if they are based on the widest possible coalitions and consultations, so the most diverse communities can claim ownership. The failure or success of the standards examined here--the Declaration on the Right to Development, the Declaration on Human Rights Defenders, the Optional Protocol to the Convention Against Torture, and the Guiding Principles on Internal Displacement-rest squarely on the nature of their constituencies and owners.

130. A number of European states, including the United Kingdom, have been accused of torture and ill-treatment before the European Committee for the Prevention of Torture and Inhuman or Degrading Treatment or Punishment. See Council of Europe website, available at http://www.cpt.coe.int/en. See also Public Statement on Turkey, Doc. CPT/Inf (93)1 (15 Dec. 1992).

131. Interview with Walter Kälin, Professor of Law, Bern University, Switzerland (3 Dec. 2002).

132. Id. 


\section{THE MULTIPLICATION OF ACTORS}

It is a fact that since 1945, the United Nations has retained its centrality as the single most important forum for standard setting and norm creation in the field of human rights. However, the UN is no longer the exclusive generator of human rights standards. Nor is an insular club of states the sole determinant of human rights norms, even though they still retain a disproportionate amount of power and influence over the content and processes of standard generation. Today, states-whatever their hue-must share the process of law making with a multiplicity of new actors, many of whom were peripheral a few decades ago. It would, nevertheless, be a mistake to conflate the increase in the number of actors with popular participation or democracy and transparency in international governance-the manner in which norms are made and how they are applied or enforced. Equally, the increased number of actors does not indicate that states are bound to demonstrate more respect for human rights standards.

\section{A. The UN Human Rights Council}

The United Nations Commission on Human Rights, which the Human Rights Council replaced in 2006, was the world's foremost human rights body and, as such, was central to the development of the most significant human rights standards. It first produced in 1948 the UDHR, which became the guidepost for other human rights instruments. The Commission was composed of fifty-three member states elected by the United Nations Economic and Social Council (ECOSOC)—roughly one quarter of UN membership-for three-year terms. Still, the Commission was never an easy forum to reach consensus or adopt human rights standards, as the experience of the UDHR and subsequent treaties and instruments has evidenced.

The new Human Rights Council has forty-seven member states that are elected by a majority of the UN General Assembly, so a candidate must garner ninety-six of 191 votes. The Council is supposed to be a departure from the Commission. Critics had accused the Commission of protecting violators, who could be elected to it through regional bloc voting. Council members will themselves be scrutinized for their human rights records and suspended if they commit gross abuses. In addition, the Council meets three times a year for ten weeks. The Commission met only once a year for six weeks. It would conduct mandatory periodic reviews of all UN members. A vote of 170 to four approved the Council, with only the United States, Israel, Palau, and the Marshall Islands voting against it. Supporters expect the 
Council to be more vigorous in opposing violator states and even-handed in addressing every country. ${ }^{133}$

Like the Commission, the Council will not affect the centrality of the state in standard setting--similar to the case with the determination of the legal status of the UDHR. The fear of a binding instrument gave way to a declaration, a document with only moral-not legal-force at its adoption. As noted by Thomas Buergenthal, the "Commission soon recognized that it would be relatively easy to adopt the text of a hortatory declaration, but that it would prove much more difficult to reach agreement on the wording of a legally binding treaty. ${ }^{\prime 134}$ The Commission's fears were proven right. It took eighteen years before the United Nations adopted the two most important general scope human rights treaties, the International Covenant on Civil and Political Rights ${ }^{135}$ and the International Covenant on Economic, Social and Cultural Rights, ${ }^{136}$ both of which were opened for signature in 1966. It then took another ten years before the two treaties came into force in 1976--a total of twenty-eight years between the UDHR and the two key binding human rights instruments. Only a number of specialized treaties, principally the Genocide Convention, entered into force during that long interlude. ${ }^{137}$

However, the UN Commission on Human Rights remained the focal point for human rights standard setting within the UN system. There were other important actors and fora where human rights standards are set. Perhaps the most significant standard setting of human rights outside the Commission took place within the International Labour Organization. The law making and supervisory machinery of the ILO that develops, monitors, and promotes international labor standards have made one of the greatest contributions to the rights of workers and to international human rights law in general. Other important standard-setters that have worked outside the Commission include the International Committee of the Red Cross, whose influence on the development of international humanitarian law is significant. Autonomous actors, working under the auspices of the Commission, such as the Special Representative on IDPs, were also important players.

The Commission, which met once a year in Geneva from the middle of March to late April, was usually a flurry of frenzied activity that was virtually all related to the setting or the enforcement of standards. Consider the figures

133. Human Rights Watch, U.N.: No Business as Usual at New Rights Council: Members Must Work Hard to Help Victims (16 June 2006), available at http://hrw.org/english/ docs $/ 2006 / 06 / 16 /$ global13567.htm.

134. BUERGentHal et Al., supra note 6, at 34-35.

135. ICCPR, supra note 63 .

136. ICESCR, supra note 63.

137. Convention on the Prevention and Punishment of the Crime of Genocide, adopted 9 Dec. 1948, 78 U.N.T.S. 277 (entered into force 12 Jan. 1951) (entered into force for U.S. 23 Feb. 1989). 
for 1999. During its six-week session that year, the Commission hosted some 3,240 persons: 587 being representatives of the fifty-three member states, 568 appearing for another ninety-one states, 217 for some twenty-nine UN agencies and other international organizations, and 1,824 representing a phalanx of 212 NGOs. ${ }^{138}$ Without exception, all these individuals and institutions sought to influence and affect one or another normative question or standard in human rights.

Significantly, the diversity of players and interests represented at the annual sessions of the Commission on Human Rights underscored the changed nature of human rights standard-setting at the UN. States, of course, remained at the center of the exercise, for it is they who must finally assent to new norms or modes of enforcement. Yet now, virtually all states-and not the traditional select few-have an opportunity to participate in these fora. Increasingly, civil society organizations-from the predictable large and influential Western international NGOs, such as Amnesty International and Human Rights Watch, to the small under-funded Southern domestic NGO - vie for a voice in the process of standard and agenda setting. Nonstate actors have dramatically impacted on law-making and norm creation in international affairs. Energized by their influence at the 1993 Vienna World Conference on Human Rights and the 1995 Beijing Fourth World Conference on Women, civil society organizations have realized their enormous clout in the creation of norms and standards.

\section{B. International and Regional Standard Setting}

Regional human rights systems have been setting their own standards since the advent of the European human rights system in 1950. Only Asia has failed to join Africa and the Americas in creating its own regional system. These regional systems in large part complement the universal UN system, although they at times have created completely new standards or tweaked existing ones to respond to the particularized political, legal, economic, historical, and cultural conditions of the regions. Thus, many actors today-from universalists to particularists-are able to lobby and campaign for the adoption of standards in the diverse fields of their interest, advocacy, and concern. One thing is clear: the multiplication of actors engaged in standard setting has opened up new possibilities for a more inclusive human rights corpus. Whether and how that promise has been actualized is a matter that needs further study.

138. Steiner \& Aliston, International Human Rights in Context, supra note 18, at 600 . See also, Theo van Boven, The Role of Non-Governmental Organizations in International Human Rights Standard-Setting: A Prerequisite of Democracy, 20 CAL. WESTERN INT'L L.J. 207 (1989). 
The three regional human rights systems in Africa, Europe, and the Americas tend to expand, elaborate, translate, or adapt universal human rights to particularized historical, political, and cultural settings. In other words, regional systems bring universal norms closer to the ground, so their implementation is more legitimate and less remote. Regional systems can break new ground and introduce novel ideas and norms in the language of the human rights movement. The African system, for example, has introduced into the corpus of human rights conceptions of duty on individuals, a new dimension in human rights. It has also given the movement the concept of peoples' rights. In other cases-the European system is a good example-regional systems have given conceptual inspiration and the power of demonstration to the universal human rights regime. Thus, regional human rights regimes can provide a more concrete forum for the elaboration of human rights standards.

Writing in 1979, Ramcharan saw the role of regional institutions as one supplementary to the international standard-setting mechanisms. Their function was to help secure greater respect for the UDHR and to serve as agents to deal with local issues. If regional bodies were to produce their own standards they must be "consistent with the Purpose and Principles of the United Nations." ${ }^{139}$ He encouraged the establishment of such organizations although he worried about their ability to faithfully stick to the universal script. ${ }^{140}$ In 2001, ${ }^{141}$ Ramcharan perceived the future evolution of regional standards as emanating primarily from local judicial decisions on economic, social, and cultural rights within a framework of the right to development. The resulting public interest jurisprudence would play its part in delivering social justice locally. In the final analysis, national systems for the protection of human rights could be tested against international norms and standards through the United Nations petitions procedures, thus, further developing the international case law of human rights protection. It speaks volumes about international human rights bureaucrats that Ramcharan worried not about the arrogance of the UN human rights system, but about the vital and necessary contributions of the regional systems.

139. UN Charter, supra note 11 , art. 52(1).

140. Bertrand Ramcharan, The Role of Regional, National and Local Institutions: Future Perspectives, in Human Rights: Thirty Years After the Universal Declaration 233, supra note 1 , at 235.

141. Ramcharan, Human Rights and Human Security, supra note 25. 


\section{THE ROLE OF NGOS IN THE CREATION OF NORMS}

\section{A. NGOs and the Human Rights Agenda}

The participation of NCOs in human rights standard setting is not a novel phenomenon. NGOs were very much present at the launch and creation of the human rights movement immediately after World War II. For instance, the Anti-Slavery Society and the International Committee of the Red Cross played important roles in the formulation of standards against slavery and standards of humanitarian law, respectively. ${ }^{142}$ NGOs actively influenced the drafting of the UDHR and later the ICCPR. ${ }^{143}$ Similarly, Rein Mullerson, formerly the Soviet member of the UN Human Rights Committee and renowned legal scholar, noted with approval the growing influence of NGOs in law making and in humanitarian law. ${ }^{144}$ In effect, NGOs permeate the entire human rights movement, not just norm creation.

[T] hey also contribute to standard setting as well as to the promotion, implementation and enforcement of human rights norms. . . . Decentralized and diverse, they proceed with a speed, decisiveness and range of concerns impossible to imagine in relation to most of the work of bureaucratic and politically constrained intergovernmental organizations. ${ }^{145}$

The term NGOs refers to a broad range of non-state actors. The terminology employed to describe the phenomenon includes "civil society," "transnational advocacy networks," or "social movements." More recently, there are references to "global civil society," a term that refers to the growing coalition of groups acting transnationally under the aegis of anti-globalization and human rights. It is clear that NGOs have become key players in international governance. At its inception, the $\mathrm{UN}$ realized the important role that NGOs could play in international affairs, although it did not appreciate just how influential NCOs would become with the passage of time. The UN gave the Economic and Social Council the authority to confer consultative

142. Steve Charnovitz, Nongovernmental Organizations and International Law, $100 \mathrm{AM}$. 1. Int'L L. 348, 353 (2006); Non-State Actors and Human Rights (Philip Alston ed., 2005); van Boven, supra note 138, at 209-10.

143. van Boven, supra note 138, at 211; Marc J. Bossurt, Guide to the "Travaux Préparatoires" of the International Covenant on Civil and Political Rights (1987). Charles Malik, one of the prominent drafters of the UDHR, noted that "non-governmental organizations, therefore, served as batteries of unofficial advisors to the various delegations [to the UN Commission on Human Rights], supplying them on a continuing basis with streams of ideas and suggestions." O. Frederick Nolde, Free and Equal: Human Rights In Ecumenical Perspective 11 (1968).

144. R.A. Mullerson, New Thinking by Soviet Scholars: Sources of International Law: New Tendencies in Soviet Thinking, 83 AM. J. INT'L L. 494, 512 (1989).

145. Steiner \& Alston, International Human Rights in Context, supra note 18, at 938. 
status on NGOs to enable them to participate in certain UN activities. ${ }^{146}$ However, this access is governed by strict rules and applies only to UN organs that fall under ECOSOC, such as the defunct UN Commission on Human Rights, and not the Security Council, the General Assembly, or the various UN human rights treaty bodies. ${ }^{147}$ Over two thousand groups now enjoy consultative status with the United Nations. Consultative status allows NGOs to "request that items be placed on the agenda of the relevant body, attend meetings, submit written statements, and make oral presentations in meetings." ${ }^{148}$ As noted by Christine Chinkin, NGOs are not merely consulted at the UN, as it was initially envisaged; they are now represented in many fora within that body:

This rather unpromising starting point [Art. 71 provision on mere consultation] has allowed the relationship between NGOs and the UN to develop, a relationship that was originally defined in terms of consultation, not representation. Nevertheless, the concept of accreditation has allowed NGO admission to intergovernmental organizations (IGOs), and fuller participation therein than could have been envisaged by the drafters of Article 71. ${ }^{149}$

The pervasiveness of NGOs in the work of the United Nations is felt more keenly than the formal rules suggest. This is particularly true in the human rights field. Where there are no formal avenues for NGO participation-as is the case with a number of human rights treaty bodies-less formal methods for NGO involvement have been devised. The initial human rights treaty bodies, like the UN Human Rights Committee, the CEDAW Committee, and the Committee on the Elimination of Racial Discrimination (CERD), did not provide formal mechanisms for NGO participation. However, most committees now recognize the need for $\mathrm{NGO}$ involvement and have introduced a variety of methods, formal and informal, which allow them to tap into the wealth of talent, information, and expertise that only NGOs possess. More recent treaty bodies include formal roles for NGOs. ${ }^{150}$

The roles of NGOs have transformed the way the UN and other normsetting fora conduct their business. Treaty bodies now plead for more in-

146. UN Charter, supra note 11, art. 71.

147. Arrangements for Consultation with Non-Governmental Organizations, U.N. ESCOR Res. 1296 (XIIV), 1520th Plenary Mtg. (23 May 1968), available at http:/www.globalpolicy. org/ngos/ngo-un/info/res-1296.htm.

148. Steiner \& Alston, International. Human Richts in Context, supra note 18, at 980. See also Michael Posner, \& C. Whittome, The Status of Human Rights NGOs, 25 Col. Hum. Rts. L. Rev. 269-90 (1994).

149. Christine Chinkin, Human Rights and the Politics of Representation: Is there a Role for International Law?, in The Role of Law in International Polttics 131, 135 (Michael Byers ed., 2000).

150. Rachel Brett, Non-Governmental Actors in the Field of Human Rights, in An INTRODUction to the International. Protection of Human Rights 399, 407 (2d ed. Raija Hanski \& Markku Suski eds., 1999). 
volvement by NGOs. ${ }^{151}$ Treaty bodies are starting to view NGOs as partners, not adversaries. With the formal inclusion of NGOs, such fora are able to receive and take into account an ever-wider and diverse range of views. This broad inclusivity has enhanced the legitimacy of standards and opened the door to a wider consensus on human rights norms. It is a long overdue recognition that as many interests as possible must be present and meaningfully participate when international institutions make decisions that affect the entire globe.

The human rights agenda, like any movement, has its leading authors who exert discernible influence on the normative development, construction, and enforcement of norms. In the field of human rights, these leaders include the United Nations, regional inter-governmental institutions, NGOs, tribunals, and academic and other conceptual writers. Of all these authors, none is more influential than international non-governmental organizations (INGOs) in setting the agenda of the human rights movement. ${ }^{152}$ It is important to note that the agenda of the human rights movement is set largely outside the corridors of the United Nations. For the most part, a few NGOs in the rich countries have largely determined what is important to the movement, but in the last decade human rights NGOs in the South have increasingly forced their concerns on the movement's agenda.

Thus, although the world of human rights NGOs is large, complex, and diverse, a few Western INGOs, have dominated the field. In order to understand how the agenda of the human rights movement has been set, one must look to these few select NGOs. These NGOs work closely with, and are allied to, some of the most influential academics and writers in the field. Some very important and notable exceptions aside, INGOs and Western academics generally share the same cultural, historical, philosophical, and conceptual framework. The two groups have been the single most important bloc of human rights actors and thinkers.

INGOs, which have been referred to as conventional doctrinalists, share with Western academics, which have been the dominant conceptualizers of the human rights movement, a broad belief in the type of society human rights standards ought to engender. ${ }^{153}$ INGOs monitor, collect, publicize,

151. Report of the Fifth Meeting of Persons Chairing the Human Rights Treaty Bodies, U.N. GAOR, 49th Sess., Agenda Item 100(a), U.N. Doc. A/49/537 (1994).

152. INGOs refer to a very select group of human rights NGOs, which are based in the most important political and cultural capitals of the West. These include Amnesty International in London, Human Rights Watch and the Lawyers Committee for Human Rights (now Human Rights First) in New York, the International Human Rights Law Group (now Global Rights) in Washington, D.C., and the International Commission of Jurists in Geneva. See Henry J. Steiner, Diverse Partners: Non-Governmental Organizations in the Human Rights Movement 19-22 (1991).

153. Makau Mutua, The Ideology of Human Rights, 36 VA. J. INT'L L. 589 (1996). 
and seek elimination of the violations of basic civil and political rights. Conceptualizers are, on the other hand, thinkers and systematizers of the human rights corpus. For both groups, however, the enforcement and application of human rights norms should lead to the type of legal-political system generally referred to as constitutionalism.

Constitutionalism must have the following five key features: political society should be based on popular sovereignty; state must be popularly accountable through various processes like genuine, periodic, and multiparty elections; governments must be controlled and limited through checks and balances and the separation of powers; the judiciary must be independent because it is the guardian of the rule of law; and the formal declaration of individual civil and political rights must be an indispensable facet of the state. Captured in the UDHR, the ICCPR, and most universal human rights instruments, these attributes have evolved from the constitutional jurisprudence of the Western liberal state. ${ }^{154}$ To INGOs and leading Western academics, the purpose of the human rights movement is to bring about this type of society.

In theory and method, INGOs are the ideological copycats of traditional Western civil rights organizations, such as, in the United States, the American Civil Liberties Union (ACLU) or the National Association for the Advancement of Colored People (NAACP). Since World War II, at least a half dozen INGOs have arisen with the express intent of promoting these values-referred to generically as human rights-throughout the world. INGOs found the perfect partner in the United Nations, the post-war body based on the vision of a world governed by the liberal state. Domestic civil rights lawyers and activists founded all the major INGOs, which include Amnesty International, Human Rights Watch, the International Commission of Jurists, the Lawyers Committee for Human Rights now Human Rights First, and the International Human Rights Law Group now Global Rights. The mandates of INGOs are virtually identical to those of their domestic counterparts. In sum, "First World" NGOs means those committed to traditional Western values associated with the origins of the human rights movement. Many of these NGOs work exclusively within their home countries, but the First World category also includes most of the powerful INGOs that investigate events primarily in the South.

As a general rule, INGOs have been reluctant to promote the adoption of standards in the field of economic, social, and cultural rights, even though the ICESCR seeks to protect those rights. It is only in the last few years that Human Rights Watch and Amnesty International have broached the area of economic and social rights. INGOs have historically been less interested in economic and social rights, which, in some cases, they resisted terming

154. Steiner \& Alston, International. Human Rights in Context, supra note 18, at 361-65, 989-91. 
"rights." Only one US INCO, the Centre for Economic and Social Rights (CESR), a relatively young organization, focuses exclusively on economic, social, and cultural rights. ${ }^{155}$ It is telling that CESR was founded in the early 1990s after the Cold War period when social and economic rights started to lose some of their communist stigma.

In 1990, Philip Alston, a former chair of the UN Committee on Economic, Social and Cultural Rights, noted Amnesty International's narrow focus on a few civil and political rights. ${ }^{156} \mathrm{He}$ argued that Amnesty International should not endorse only a selective conception of rights, ones which "mirror more closely value associated with the Western liberal tradition." ${ }^{157}$ Alston argued that Amnesty could endorse the totality of human rights, including economic, social, and cultural rights, while maintaining work on its core issues for "manageability, legal specificity and operational potential." 158 He called on Amnesty to lead by embracing all human rights, including economic, social, and cultural rights. ${ }^{159}$

Unfortunately, many domestic human rights NGOs in the South have replicated the Amnesty International model and mandate. A large number focus their work on civil and political rights, although in the last decade many groups have arisen in the South to address specifically matters of economic, social, and cultural rights. ${ }^{160}$ Some older NGOs are also revising their mandates to accommodate advocacy on a broader range of human rights. Yet domestic NGOs in the South tend to be elitist and urban-based oftentimes divorced from the people on whose behalf they advocate. These NGOs are funded by Western foundations, charities, and the development agencies of donor states, such as the United States Agency for International Development (USAID). These NGOs do not have significant local funding and are tightly tethered to their foreign benefactors, whom Willy Mutunga, the former Executive Director of the Kenya Human Rights Commission, the most influential human rights NGO in Kenya, referred to as "our foreign masters. ${ }^{\prime 161}$

155. The Centre for Economic and Social Rights was founded in New York in 1993. It seeks to promote social justice through human rights. For more information see their website, available at http://www.cesr.org. A review of other INGOs shows that none of them focus primarily on economic, social, and cultural rights. See Mutua, The Ideology of Human Rights, supra note 153, at 617-20.

156. Philip Alston, The Fortieth Anniversary of the Universal Declaration of Human Rights: a Time More for Reflection than for Celebration, in Human Rights in a Pluralist Worlo: Individuals and Collectivities 1, 9 (Jan Berting et al. eds., 1990).

157. Id.

158. Id.

159. $I d$.

160. The Nigerian Lagos-based Social and Economic Action Rights Centre (SERAC), which was founded by Felix Morka, a Nigerian human rights advocate, has become a leader on economic and social rights in Nigeria.

161. Interview with Willy Mutunga, Executive Director, Kenya Human Rights Commission, Nairobi, Kenya (26 Aug. 2002). 
Most NGOs in the South pursue donor interests because of this dependent relationship. These interests often do not converge with the local human rights agenda, which robs them of the freedom and desire to participate robustly in setting the agenda of the global human rights movement. While these trends are being challenged, and may be more acute in Africa than in Latin America or Asia, the funding for human rights groups throughout the world primarily comes from the West. As Chidi Anselm Odinkalu, an African human rights thinker-activist has written, such alienation and dependency cannot be healthy or anchor the movement in the grassroots. ${ }^{162}$

There are other structural problems that make it impossible for NGOs in the South to meaningfully participate in the setting of human rights standards. In virtually all categories, NGOs in the South are no match for INGOs. The latter receive enormous funding from donors and have access to powerful states and their media. Often, NGOs from the South cannot muster adequate resources required for sustained foreign travel and lobbying at the UN fora in New York and Geneva, where INGOs market their agenda for the human rights movement. Most of these problems are a reflection of geopolitical power imbalances. Coalition building across borders between INGOs and NGOs is required to alleviate this disequilibrium. Otherwise, INGOs will continue to enjoy disproportionate influence in determining the agenda of the human rights movement.

\section{B. NGOs and Standard Setting}

States have a distaste for norms that tend to encumber their sovereignty. States are, in this respect, conservative institutions. Inter-governmental institutions (IGOs), such as the United Nations, are vehicles for creating international standards and harmonizing the rivalries among states. IGOs are at their core statist institutions whose purpose is to allow states to dialogue with each other. States are the key actors in IGOs and are also their primary targets. Fundamentally, IGOs exist to further the interests of states. NGOs, on the other hand, are not statist by definition, intent, or purpose. They exist to influence officialdom. They seek to tame, limit, and contain the power of the state. NGOs are supposed to be the conscience of the citizenry, the defender of the interests of civilian populations against impermissible encroachment by officialdom. NGOs cover the entire ideological spectrum from the extreme left to the fundamentalist right. They range from the selfless to the self-seeking. ${ }^{163}$

162. Chidi Anselm Odinkalu, Why More Africans Don't Use Human Rights Language, Hum. Rts. Dialocue 3-4 (2000).

163. The diversity of NCOs is captured by their acronyms: CBOs (community-based organizations); PVOs (private voluntary organizations); GONGOs (government organized NGOs); DONGOs (donor organized NGOs); CSOs (civil society organizations); MONGOs 
NGOs are distinguished from both the state and IGOs because of the place of advocacy in their raison d'être. Virtually all NGOs have an advocacy dimension and most exist for that purpose. NGOs fight to create or influence standards and how those standards are implemented or enforced. They want to exert influence over rules, laws, and policies so that practice can be impacted. Ultimately, NGOs are most concerned about outcomes, not processes, unless process is the outcome sought. NGOs are activist and consequentialist that do not see themselves as conceptualizers. NGOs view themselves as doers and implementers, although the reality is far more complex. It is this activist essence of NGOs that makes them potential leaders in society. Unfettered by the constraints of public power and largely unaccountable to the state or the public, NGOs can be quick, decisive, and edge cutting.

Most NGOs are not suffocated by bureaucracy or limited by democratic governance, so they can respond quickly to a variety of situations, including seemingly paralyzing crises. States and IGOs usually need either consensus or broad and prolonged consultations to arrive at a decision. They are also subject to gridlock and bureaucratic and democratic constraints. These factors breed inertia and inability to act decisively and quickly, if at all. Shorn of these limitations-and unfettered by operational conservatism-NGOs have seized the initiative in setting standards in the field of human rights. Since 1945, the impact of NGOs has risen steadily in this respect. NGO input in standard setting has been evident within the African Commission on Human and Peoples' Rights, ${ }^{164}$ the Council of Europe, the International Labour Organization, and the Organization of American States, among others. ${ }^{165}$ At the international level, and especially within the United Nations, which remains the central forum for human rights norm creation, NGOs have unquestionably become leaders.

The development of standards to proscribe torture and ill treatment of citizens owes its genesis and realization to a few NGOs. ${ }^{166}$ The Convention Against Torture and Other Cruel, Inhuman or Degrading Treatment or Punishment can be directly traced to Amnesty International. In 1972, Amnesty launched amid fanfare a yearlong campaign for the abolition of torture. ${ }^{167}$ The campaign included the publication of a report on torture and an inter-

(my own NGOs); FANGOs (family NGOs); INGOs (international NGOs); QUANGOs (quasi-government NGOs); and BINGOs (business and industry NGOs).

164. Chidi Anselm Odinkalu, The Individual Complaints Procedures of the African Commission on Human and Peoples' Rights: A Preliminary Assessment, 8 Transnat't L. \& Contemp. Probs. 359 (1998).

165. Van Boven, supra note 138, at 212.

166. Virginia Leary, A New Role for Non-Governmental Organizations in Human Rights: A Case Study of Non-Governmental Participation in the Development of International Norms on Torture, in UN Law/Fundamental Rights: Two Topics In International Law 197-210 (Antonio Cassese ed., 1979).

167. van Boven, supra note 138, at 213. 
national conference. These events helped create public awareness and raise the international concern over the problem of torture. The existence of brutal regimes in Latin America and Africa added momentum to the gathering cries for the development of standards for the prevention of torture.

In a 1975 report on torture, Amnesty International became the first organization to develop a definition of torture. ${ }^{168}$ In the same year, the UN adopted the Declaration on the Protection of All Persons From Being Subjected to Torture and Other Cruel, Inhuman or Degrading Treatment or Punishment. ${ }^{169}$ This was the first UN document on torture. It was followed by the adoption of the Code of Conduct of Law Enforcement Officials in $1979^{170}$ and the 1982 Principles of Medical Ethics Relevant to the Role of Health Personnel, particularly Physicians, in the Protection of Prisoners and Detainees against Torture and Other Cruel, Inhuman or Degrading Treatment or Punishment. ${ }^{171}$ These documents were the forerunners to the 1984 Torture Convention. The former UN Special Rapporteur on Torture Theo van Boven has acknowledged the central roles played by NGOs in developing these instruments and standards against torture.

Most of these instruments were the product of consistent and skillful efforts of governmental and NGO experts. On the governmental side, Netherlands and Sweden contributed substantially. On the NGO side, credit should go to Amnesty International and the International Commission of Jurists for their lobbying and skillful drafting work, with the constant aim of enhancing the level of protection. It is beyond the scope of this article to review in detail all of the NGO input into these instruments, which ranged from proposals for entire documents to the presentation of draft articles or amendments. For example, NGO efforts were entirely responsible for the 1982 Principles of Medical Ethics, which subsequently received formal endorsement from the UN General Assembly. ${ }^{172}$

NGOs were also the key players in starting discussions on new standards to amend the Torture Convention to make it more effective. While

168. According to Amnesty International, torture includes the following essential elements in its definition: (1) the involvement of at least two persons, the torturer and the victim; (2) an implication that the victim is under the physical control or restraint of the torturer; and (3) the infliction of acute pain or suffering on the victim by the torturer. AMNESTY International, Report On Torture, 30 (1975).

169. Declaration on the Protection of All Persons from Being Subjected to Torture and Other Cruel, Inhuman or Degrading Treatment or Punishment, G.A. Res. 3452 (XXX), U.N. GAOR Supp. (No. 34), U.N. Doc. A10034 (1975).

170. Code of Conduct for Law Enforcement Officials, adopted 17 Dec. 1979, U.N. G. A. Res. 34/169, U.N. GAOR, 34th Sess., U.N. Doc. A/RES/34/169 (1979).

171. Principles of Medical Ethics relevant to the Role of Health Personnel, particularly Physicians, in the Protection of Prisoners and Detainees against Torture and Other Cruel, Inhuman or Degrading Treatment or Punishment, adopted 18 Dec. 1982, G.A. Res. 37/194, U.N. GAOR, 37th Sess., Supp. No. 51, at 211, U.N. Doc. A37/51 (1982).

172. van Boven, supra note 138, at 214-15. 
some states were also instrumental in their support of the Draft Protocol to the Torture Convention-most notably, Mexico, Costa Rica, Switzerland, and Denmark-it was NGOs who provided the vitality and energy. This was particularly the case when certain states, such as the United States, India, China, and others, wanted to stall the Draft Protocol. NGOs pushed to overcome the resistance and inertia of the IGO, in this case the Commission on Human Rights. Critical to this breakthrough was the partnership between a number of governments and NGOs. NGOs also led in the creation of standards for the Declaration on Human Rights Defenders. Some governments had argued that the instrument was sensitive and intrusive. ${ }^{173}$ In fact, many states did not want human rights NGOs given protection in a single visible instrument with a mandate to hold the states accountable. This explains the inexplicably long period of twelve years that it took to agree to a restatement of existing obligations. Even in this case NGO leadership alone would not have been enough. NGO-state partnership was indispensable, and Norway led the other states in mustering support for the Declaration.

NGOs have also been catalysts in advancing the rights of indigenous peoples. In 1982, the UN created a Working Group on Indigenous Populations of the UN Sub-Commission on Prevention of Discrimination and Protection of Minorities. The Working Group immediately started work on a draft declaration on the rights of indigenous peoples. Indigenous peoples had been largely invisible to the UN human rights until the late 1980 s when José Martinez Cobo, the Special Rapporteur of the UN Sub-Commission on the Prevention of Discrimination and Protection of Minorities, produced a report on their plight. ${ }^{174}$ To this day, there are only two universal binding instruments that address specifically indigenous peoples and both are in labor rights. ${ }^{175}$

The Sub-Commission Working Group became the focal point for the advocacy of standards on indigenous populations. An incredible 135 NGOs, the majority of them indigenous peoples' organizations, were represented in the Working Group. ${ }^{176}$ In 1994, the Working Group produced the UN Draft Declaration on the Rights of Indigenous Peoples. The UN Sub-Commission then adopted the Declaration and forwarded it to the UN Commission on Human Rights where it has languished until 29 June 2006 when it was

173. Interview with Carmen-Guevas, supra note 77.

174. Jose R. Martinez Cobo, Study of the Problem of Discrimination Against Indigenous Populations (FINAL Report), U.N. Doc. E/CN.4/Sub.2/1986/7Add.4 (1987).

175. Convention Concerning Weekly Rest (Commerce and Offices) (ILO No. 106), adopted 26 June 1957, 325 U.N.T.S. 279; Convention Concerning Indigenous and Tribal Peoples in Independent Countries (ILO No. 169), adopted 27 June 1989, 1650 U.N.T.S. 383, (entered into force 5 Sept. 1991), reprinted in lan Brownlie, Basic Documents in Human RiGiHTs 303 (3d ed. 1992).

176. Report of Working Group on Indigenous Populations, U.N. ESCOR, Comm'n on Hum. Rts., 7th Sess., U.N. Doc. E/CN.4/Sub.2/1989/36 (1989). 
adopted by the UN Human Rights Council. Again, the beneficiaries of a human rights instrument organized into NGOs and were able to draft an instrument to promote and protect their rights. It is important to note that the UN Sub-Commission, traditionally the UN body most sympathetic to human rights because it was composed of independent experts, not government representatives, adopted the Draft Declaration. The Draft Declaration was opposed by many states because it sought to give indigenous peoples a significant degree of cultural, economic, and political autonomy. It was seen by many states as a threat to their sovereignty and a challenge to their authority. One thing is clear: the Draft Declaration would not have been possible but for the tireless efforts of indigenous peoples' NGOs. This is one case where the victims developed the standards by which they want to be governed.

However, the long delay by the Commission on Human Rights in adopting the Draft Declaration raises questions about the normative content of the instrument as well as the strategy employed by the indigenous peoples NGOs in crafting it. Did the NGOs fail to ally themselves and partner with key states? Were there no states willing to be drafted into this campaign? Was the Draft Declaration another victim-like the Declaration on the Right to Development-of powerful states and private interests that felt threatened by it? Is it fair to conclude that the international legal order was not yet ready to address the plight of indigenous peoples, one of the most vulnerable populations on earth, in a meaningful way? Even so, some scholars had predicted that the Draft Declaration was likely to be adopted in the near future. ${ }^{177}$

NGOs have also been leaders in the campaign for women's human rights. Although the last two decades have witnessed tremendous strides in the recognition by the international legal order of the rights of women, women's rights have been a blind spot in the human rights movement. In contrast to its tenacity in addressing the problem of racial discrimination, the human rights movement's relative silence on the violations visited on women by men, states, cultures, and societies is important. Hilary Charlesworth and Christine Chinkin have argued persuasively that jus cogens-a term that denotes a peremptory, universal, and superior legal norm that cannot be derogated from - has a male gender and is discriminatory of women in its human rights dimensions. ${ }^{178}$

In the last two decades, however, NGOs have made women's rights visible in the standard-setting agenda of the human rights movement. Apart from CEDAW, which is regarded as a breakthrough convention, there have

177. Steiner \& Alston, International Human Rights in Context, supra note 18, at 1301-02.

178. Hilary Charlesworth \& Christine Chinkin, The Gender of Jus Cogens, 15 Hum. RTs. Q. 63 (1993). 
been several developments that have brought women's issues to the forefront. Women's NGOs have become so successful that they are now seen as a model for how NGOs ought to intervene and elevate the issues they advocate. The first of these significant developments was the affirmation at the Vienna World Conference on Human Rights that the "human rights of women and of the girl-child are an inalienable, integral and indivisible part of universal human rights." ${ }^{\prime 79}$

During the same year, the General Assembly adopted by consensus the UN Declaration on the Elimination of Violence against Women. ${ }^{180}$ In 1994, ECOSOC decided to create the position of Special Rapporteur on violence against women and appointed Radhika Coomarasawamy, the Sri Lankan human rights advocate, who served from 1994 until July 2003. Other significant gains included the explicit inclusion of sexual crimes against women in the statutes of the Yugoslav and Rwandan international criminal tribunals. ${ }^{181}$ The Rome Statute for the International Criminal Court has followed suit in this regard. Chinkin points out that these gains are attributable to the advocacy of women's NGOs, which have perfected the art of networking at the local, national, and international levels. ${ }^{182}$

There is no shortage of examples where NGOs have become the leading force behind standard setting in human rights. Whether it is in regard to torture, women's rights, the campaign to ban landmines, ${ }^{183}$ labor rights, or the rights of indigenous peoples, NGOs have become the animators of the international standard setting bodies within the United Nations. It bears keeping in mind, however, that the success of NGOs has come with more sophistication on their part. Whether it is finding partners or networking across borders, NGOs seem to have the formula for eliciting favorable responses from law-making processes.

\section{NGO Strategies and Methods in Standard Setting}

NGOs exhibit a love-hate relationship with states and IGOs, depending on the effect of the standard on state sovereignty. This complexity leads NGOs to act as both partner and pressure group in their relationship with states and IGOs in standard-setting fora. In deploying these strategies, NGOs have

179. Vienna Declaration, supra note 55 , I 18.

180. Declaration on the Elimination of Violence Against Women, supra note 53.

181. Statute of the International Criminal Tribunal for the Former Yugoslavia, art. 5(g), SC Res. 827, U.N. Doc. S/RES/827 (25 May 1993); Statute of the International Criminal Tribunal for Rwanda, art. 3(g), SC Res. 955, U.N. Doc. S/RES/955 (8 Nov. 1994).

182. Chinkin, supra note 149 , at 133-34.

183. Convention on the Prohibition of the Use, Stockpiling, Production and Transfer of AntiPersonnel Mines and their Destruction, I 8, 2056 U.N.T.S. 211 (18 Sept. 1997). 
frequently used a divide-and-conquer approach towards states. Often, NGOs will target a friendly state and use it as the vehicle for the purveyance of their intentions. NGOs will also use the friendly state to gauge the intentions of an opposing, reluctant, or opaque state. Since states tend to listen more to each other than to NGOs, a state that is NGO-friendly will be used to win over a resisting state. This partnership approach was employed by NGOs in their campaign for the adoption of the Draft Optional Protocol to the Convention against Torture. ${ }^{184}$ This was replicated by NGOs to advance other standards.

The struggle for the Convention on the Rights of the Child (CRC) saw an innovation of the partnership model. Although the drafting of the CRC began in 1980, it was not until 1984 that it started in earnest. Not surprisingly, the entry of NGOs into the drafting process jump-started the exercise. Once the drafting started, the process became less political and more technical, a development that gave NGOs, largely the only actors with new ideas, an upper hand. ${ }^{185}$ In 1987, the United Nations Children's Fund (UNICEF) joined the campaign for the CRC by funding NGO meetings to come up with common approaches and strategies. ${ }^{186}$ The cooperation between NGOs and UNICEF in standard setting was innovative and critical to the success of the CRC. As noted by one writer, it is "generally acknowledged in the international community that the NGOs had a direct and indirect impact on this Convention that is without parallel in the history of drafting international instruments." ${ }^{187}$ The partnership between NGOs and UNICEF, along with the unusually close relationship between NGOs and states in the drafting and adoption of the CRC, has attracted particular attention. In effect:

[T] he success of the NGOs' activities to promote support for the Convention was, for example, undoubtedly instrumental in getting many governments to take the drafting process more seriously, and in giving the Working Group a renewed sense of purpose. This was all the more so when, in 1987, the NGO Group joined with UNICEF in publicly promoting the objective of having the Convention ready for adoption by the UN General Assembly in 1989. Furthermore, the Group's proposals were increasingly being presented by government delegates during the Working Group meetings, rather than directly by the NGOs themselves. ${ }^{188}$

184. Interview with Kälin, supra note 131.

185. Interview with David Johnson, Secretary to the Committee on the Rights of the Child, Human Rights Officer, UN Office of the High Commissioner for Human Rights, Geneva, Switzerland (4 Dec. 2002).

186. Id.

187. Nigel Cantwell, The Origins, Development and Significance of the United Nations Convention on the Rights of the Child, in The United Nations Convention on the Richts of the Child: A Guide to the "Travaux Preparatoires" 19, 24 (Sharon Detrick ed., 1992).

188. Id. at 25 . 
The campaign for the drafting and adoption of the Landmines Convention saw NGOs deploy an array of strategies against states and IGOs. These ranged from negative publicity, pressure, lobbying, and eventually partnership. The campaign, which was initially launched by the International Committee of the Red Cross, was quickly taken over by a coalition of Western INGOs: Human Rights Watch, Physicians for Human Rights, and the Vietnam Veterans Associations of America (United States); Handicap International (France); Medico International (Germany); and Mines Awareness Group (United Kingdom). These INGOs formed the core of the International Campaign to Ban Landmines and were later joined by some 1,200 NGOs from sixty states. ${ }^{189}$

Although most states were initially either disinterested or opposed to the idea of a ban on landmines, the sophisticated deployment of pressure, persuasion, lobbying, and publicity about the terrible havoc wreaked by landmines led sympathetic and like-minded states to spearhead the ban. ${ }^{190}$ The lesson here is that NCOs would use the entire arsenal of strategies at their disposal to force the adoption of a standard. It was also clear to INGOs that a wide coalition of NGOs, many of them domestic, was essential for the pressure and public relations campaign to work. The achievement of the Landmines Convention is ample proof that NGOs can prevail over reluctant and recalcitrant states to adopt even what many of them regarded initially as a "pie-in-the-sky" treaty. ${ }^{191}$

The partnership and lobby model, where NGOs target states, has been most successful where the NGOs themselves form one united front and campaign as a unit with common proposals. This means that NGOs have first had to forge unity among themselves before confronting or reaching out to states or IGOs. NGOs realize that in unity, diversity, and numbers there is strength and credibility. In fact, coalition-building among NGOs and creation of the broadest possible networks among them is the main reasons behind the recent successes of the human rights movement. This was clearly the case with the drafting and adoption of the CRC. Large, Western INGOs were intent on presenting a united front before states to which they would sell common proposals. States then took over most of these proposals and presented them as their own. These coalitions of NGOs and states were so active and powerful that even those states that had been reluctant originally came on board. The broad inclusion of various actors allowed many groups to claim ownership. This is what has led to the spectacular success of the CRC. ${ }^{192}$

189. Kenneth Anderson, The Ottawa Convention Banning Landmines, The Role of International Non-Governmental Organizations and the Idea of International Civil Society, 11 EUR. J. INT'L L. 1, 91 (2000).

190. Id.

191. Id.

192. Interview with Johnson, supra note $\mathbf{1 8 5}$. 
The most visible demonstration of the success of coalition building and networking has been in the impressive strides made in setting standards on women's rights. Women's groups had been frustrated within UN fora since the 1970 s because they were excluded from standard-setting bodies. Between the 1985 Nairobi and 1995 Beijing UN women's conferences, women quickly organized themselves and improved greatly their lobbying techniques. They built coalitions through caucuses, participated in strategymaking preparatory meetings before $U N$ conferences, and increased contacts with the media and national delegations. ${ }^{193}$ Barely a subject of international conversation two decades ago, women's rights today dominates virtually every effort in international affairs. "Women's NGOs have developed ways of maximizing their impact upon diplomatic negotiations, either directly or indirectly through the inclusion of their representatives in state delegations or indirectly through consciousness-raising activities, intensive and careful work on draft texts, campaigning at the national, regional and international levels and the formation of caucuses and international coalitions." ${ }^{194}$

NGOs are critical to the work of standard setting because as practitioners of human rights they are closer to victims than states and are better able to identify the gaps in standards, as well as the weaknesses in implementation. Many NGOs also have real expertise in particular issues and countries. This proximity to the grassroots and the prevalence of expertise makes NGOs purveyors of accurate information and a good source of analysis on standards and their weaknesses. Many states lack the capacity or political will to obtain such data, information, and analyses. As a result, many states and IGOs are often quite happy to accept or benefit from NGO expertise and knowledge. For their part, NGOs adopt a very instrumentalist approach to their relationship with states and willingly provide free advice and information. This allows NGOs to use information and expertise to manipulate states and IGOs. The bottom line, however, is that states have become ever more reliant and dependent on NGOs for advice, expertise, and information. It is such reliance and dependence that have made NGOs indispensable to the work of states and IGOs in standard setting.

\section{NGOs and States Play Hide and Seek}

The reliance and dependence of states on NGOs does not mean that the two antagonists have become one. Nor does it point to a common vision. States remain the repositories of sovereignty and the key actors in IGOs. It

193. Ann Marie Clark, Elisabeth J. Friedman \& Kathryn Hochstetler, The Sovereign Limits of Global Society: A Comparison of NGO Participation in UN World Conferences on the Environment, Human Rights, and Women, 51 WorLd Pol. 1, 15 (1998).

194. Chinkin, supra note 149 , at 137. 
is the states - not the NGOs-who formally make international human rights law. IGOs represent states, and it is still their prerogative to choose which non-state actors can be given access to them. Non-states actors selected to be in the deliberations of IGOs by states; they do not belong there as of right. Hence, the relationship between state and non-state actors within IGOs is a matter of tension and is subject to further evolution. What is not in doubt, however, is the fact that NGOs have achieved unprecedented access and influence in UN human rights standard-setting fora. It is difficult to see how states can claw back this access or curtail the reach of NGOs within IGOs. Despite these achievements, a careful analysis of the relationship between IGOs and NGOs reveals a more complex picture-one that suggests an unsettled and uneasy co-existence between them. What emerges is the image of two civil opponents circling each other distrustfully-like a cat and a mouse-while at the same time finding areas of accommodation and agreement.

States have not passively accepted NGOs advances. Fundamentally, states regard NGOs as intruders whom they welcome ruefully and reluctantly. States rarely concede to NGOs' standards that are truly costly to their sovereignty. There is usually a catch in cases where states appear to have conceded too much. States may either seek cover under a weak enforcement regime or obtain relief through reservations. Even in situations where it is agreed that a certain treaty or standard is defective normatively and institutionally- such as with the Torture Convention-states may agree to an optional protocol instead of revising the treaty itself. States are then free to ratify or reject the optional protocol. The Optional Protocol to CAT is the classic example of this exercise, where the document itself substantially raises the cost of joining and, in fact, prompts many states to oppose it. Nevertheless, states are wary of NGOs and will not hesitate to retreat behind the veil of sovereignty and their control of IGOs to limit the influence of NGOs and resist the most biting of norms. The relationship between NGOs and states or IGOs expands and contracts according to the issues.

States retain the exclusive power to decide the type of normative instrument that may be adopted by an IGO. Where states feel threatened by a proposed standard, they may allow its adoption, but as a declaration and not a treaty. Thus, states may give in to NGO demands for a standard but consign it to the soft law status of a declaration, resolution, or a platform of action, such as was the case with the 1995 Beijing Fourth World Conference on Women. The Declaration on Human Rights Defenders and the Declaration on the Right to Development were most likely agreed to by states because of their soft law status. It is unlikely that states would have agreed to them as treaties. Soft law norms generally lack clear performance targets, compliance dates, and a commitment by the state to expend resources. ${ }^{195}$

195. Id. at $140-41$. 
Hard law instruments like treaties are unpopular with states because they are generally based on clear-cut commitments. Admittedly, NGO access in the drafting of a treaty does not guarantee that the final product will reflect the wishes of the global civil society. The presence of an astounding 130 NGOs in Rome did not prevent states from striking a compromise over the final text of the Statute of the International Criminal Court. ${ }^{196}$

NGOs have a lot of work to do to increase their space and access to IGOs. States can play any variety of tricks or games to limit or suppress NGO participation in standard setting. These range from failing to include NGO items on the agenda, denying NGOs access to certain conference sessions (as happened in the Fourth World Conference on Women in Beijing), refusing NGO representatives accreditation to UN meetings, allocating NGO participants little, if any, speaking time, and failing to facilitate visa and other travel arrangements to meetings. Many of these actions may look petty, but they can frustrate NGOs and result in their failure to carry out an effective campaign to advance a standard or adopt an important instrument. NGOs must also resist the temptation of power and make sure that access is not used to capture and coopt more radical and transformative agendas. ${ }^{197}$ It is promising, however, that there usually is a number of states within any UN meeting that are willing to counter the obstructionist agendas of some states. The larger and more inclusive the NCO coalition the better the chances of gaining access.

\section{THE QUESTION OF DEFICITS}

A persistent problem of norm setting--in human rights and other areas-is the question of deficits. These deficits are understood to be shortcomings and gaps that result in illegitimacy, incompleteness, ineffectiveness, and exclusion. These gaps are related to the actors and the manner of their participation. The two most important deficits in human rights standard setting are in participation and democracy. Is participation broad and inclusive? What is the nature of the participants, and are they representative of the widest diversity of interests, views, and traditions? Is the process of participation transparent and democratic? Do states have an equal voice, and if not, why? Do all non-state actors have access and opportunity for democratic participation? Can these deficits be filled? Whose responsibility is it to cure them, and how can they be addressed?

196. Id. at 141 .

197. Dianne Otto, A Post-Beijing Reflection on the Limitations and Potential of Human Rights Discourse for Women, in 1 Women and International Human Rights Law Vol. 1, 115, 135 (Kelly D. Askin \& Dorean M. Koenig eds., 1999). 


\section{A. The Deficit of Numbers}

At the dawn of the human rights movement, deficits of participation and democracy existed. In the late 1940s, a few Western states controlled the process of standard setting exclusively, although some NGOs from the North sought to influence the United Nations from the margins. It is ironic now-over fifty years later-that the drafting of the UDHR was so closely held among such an exclusive group. This exclusivity was a reflection of the global power hierarchies of the day. Africa, for instance, was virtually absent from the participants because almost the entire continent was held in colonial bondage by several European states. This deficit of numbers has been steadily lowered over the years, and the crafting of successive UN human rights documents has been open, at least formally, to all member states of the United Nations, who today number 191. Yet numbers only address the numerical deficit and not the gaps in participation and democracy.

The deficit of numbers with respect to non-state actors is not the acute problem it was at the launch of the human rights movement. Domestic human rights NGOs have mushroomed in virtually every state in the South over the last several decades. Some of these NGOs have become quite sophisticated in their advocacy and lobbying work. A number have developed working relationships with consumer and social justice movements in the South and the North. ${ }^{198}$ They are part of an emerging global civil society that seeks standards in response to the excesses of globalization. However, the increase in the numbers of NGOs in the South does not necessarily translate directly into additional voices within the United Nations. International lobbying and networking requires enormous resources for organization, travel, and communication, which most NGOs in the South cannot afford. Even when they travel to Geneva, New York, and other norm-making venues, such NGOs remain outsiders, out of their element, and far away from home. Numbers alone only tell part of the story.

Lobbying and networking within the corridors of the UN fora are activities that require expertise, enormous resources, and access to powerful actors. The civil society movement in most of the South is still young, poor, and not well connected to influential media outlets in the West or key actors in international forums, such as the UN. This position is no doubt improving, and a number of NGOs from the South are increasingly becoming adept at lobbying within $U N$ corridors. But their voices remain marginalized because of the disparity in resources and access to the political and cultural centers of power in the North. As more NGOs from the South become stronger, their voices will carry more weight.

198. Interview with Steve Ouma, Program Officer, Kenya Human Rights Commission, Nairobi, Kenya (Jan-Feb. 2003). 


\section{B. The Deficit of Participation}

Numerically, the South dominates the UN General Assembly, but its voice is less effective and could be exercised more meaningfully in standard setting. States from the North still dominate the UN human rights norm making bodies. There are several reasons for this state of affairs. First, and perhaps most important, donor or capital exporting states have a disproportionate voice in international organizations. Their influence and power over institutions of global governance cuts across the entire spectrum of international dealings. The sense that the North "owns" the organs of international governance pervades them. The domination of the UN Security Council by the United States and the United Kingdom over Iraq is one of the most glaring example of this domination. ${ }^{199}$

Such asymmetry of power allows states from the North to exert their will over IGOs and have their concerns addressed. ${ }^{200}$ The Optional Protocol to the Torture Convention is a good illustration of this fact. It was natural that many states from the South would oppose the Optional Protocol because it was mainly targeted at them. However, the Protocol was adopted-over US opposition-because a powerful coalition of European and Latin American states supported it. ${ }^{201}$ The Declaration on Human Rights Defenders, too, owes its success to the leadership of Norway and heavy support from most of Europe. In contrast, the Declaration on the Right to Development lacks powerful supporters.

The South suffers from other complex, but related, influence problems. The delegations of most states in the South lack adequate expertise in human rights, international law and related fields. This is not only a direct result of their poor economies, but also a function of bad governance and an absence of coherent foreign policies, among other factors. The combination of these factors lead to ill-prepared delegations, unable or unwilling to advocate effectively for their positions. ${ }^{202}$ Instead, most delegations from the South engage in high but empty rhetoric, devoid of serious analysis and development of the issues into law-like formulations. ${ }^{203}$ Moreover, many states in the South are suspicious of human rights NGOs and do not have cordial relations with them, unlike their counterparts in the North. This hostility extends to both domestic NGOs and INGOs. Nor do states in the South

199. Ian Martin, The New Worlo Order: Opportunity or Threat for Human Rights, Lecture at the Harvard Law School human Rights Procram 10 (1993).

200. IGOs are usually dominated either by a single state or a coalition of elite states because of their military, economic, or other hegemonic power, as is the case with the United States and the United Nations. See Ernest HaAs, When Knowledge is Power: Three Models of Change in International Organizations 7 (1990).

201. Interview Carmen-Guevas, supra note 77.

202. Interview, Oloka-Onyango, supra note 113.

203. Id. 
usually consult human rights scholars for advice. Consequently, states in the South do not benefit from the valuable help and expertise that NGOs can offer. This places them at a considerable disadvantage to states in the North whose skilled technocrats normally accord NGOs more open access, so they can tap into their expertise and advice. Delegations from the North are also adept at using academics and think-tanks as resources to keep them abreast of cutting-edge thinking and recent developments. The Swiss government's efforts in support of the Optional Protocol to CAT is a model demonstration of how government, intellectuals, and NGOs can successfully harness and pool their resources and skills to advance an agenda. ${ }^{204}$

There is every reason for states in the South to develop and cultivate democratic, transparent, and inclusive approaches to governance. This should mean involving local NGOs and academics in advising the state and its institutions-particularly the ministry of foreign affairs—on a wide range of important questions of national interest. The skills and resources in the NGO world can go a long way in plugging the lacunae in the capacity of the state to participate ably in standard setting. States in the South are better advised to include academics and NGO representatives, who often have good contacts with their counterparts in the North, in official delegations to UN standard-setting and other bodies. Such an ameliorative step will not, of course, radically alter the imbalance of power between the North and the South. It will, however, at least allow states in the South to maximize and more fully utilize the resources and skills available at home. Some states in the South, such as Costa Rica and Senegal, have long reached into their civil societies and universities to staff and revamp their efforts in international affairs.

INGOs are adept at lobbying for human rights standards and their implementation. Amnesty International and Human Rights Watch have in particular been key leaders in the work of standard setting within ICOs. Although NGOs from the South have become increasingly active in ICO circles, they remain "outsiders." There is an unhealthy division of labor between regional and domestic NGOs and INGOs, where the latter engage in international human rights work, which means initiating and leading NGO efforts within ICOs, while the former focus on human rights problems in their native lands, or act as funnels for information to INGOs. This dichotomy perpetuates the weaknesses of NGOs in the South while at the same time entrenching the privileged position of the INGOs. Larry Cox, the American human rights advocate, has decried this lopsided relationship between Southern NGOs and Western INCOs. He notes:

[T] he problem is that ... [i]nternational work is still for the most part the domain of groups located in the North. Groups in the South are still seen largely as

204. Interview with Kälin, supra note 131 . 
domestic partners or as "human rights defenders" who are protected by those doing international work. The possibility for groups outside Western Europe and the United States either to set the agenda for human rights or even to influence, as equal partners, the strategies set by international groups for their countries is very limited. To change this would take a much deeper commitment than currently exists on the part of either donors or NGOs to invest in travel, discussions and the alteration of old patterns. ${ }^{205}$

More recently, INGOs have increased their efforts at coalition building and networking with NGOs in the South. INGOs believe that such coalitions lend more legitimacy to their work. These coalitions have been developed in the campaigns for standards on questions related to globalization, land mines, and women's rights. ${ }^{206}$ Even so, Western INGOs led these coalitions. This inclusivity was not intended to empower NGOs from the South but rather to strengthen the NGO voice. As noted by a critic, the "forming of [such] coalitions may allow for a single, and therefore more forceful, NGO voice, but this may also conceal deep divisions among those within the coalition." 207 The dissenting views of NGOs from the South may be suppressed so as to give the appearance of a united global civil society. This has been a problem in the struggle for women's rights. NGOs from the South have pointed to the reluctance of their counterparts from the North-who dominate international standard-setting fora in the field-to address issues pertinent to them. ${ }^{208}$ This has resulted in the universalization of the priorities of women in the North and the concomitant downgrading of the problems that women in the South face. That is precisely what one study revealed. It noted:

This viewpoint emerged in a survey of NGO attitudes in which seventy per cent of those questioned expressed their concerns about the domination by larger, white, English-language NGOs. One survey concluded that "prejudices of racism, sexism and colonialism still endure" despite the apparently more open texture of civil society. ... Increased representation is justified in terms of the potential empowerment of those previously lacking power, but great care must be taken in identifying who in fact is benefiting from the process. ${ }^{209}$

205. Larry Cox, Reflections on Human Rights at Century's End, 2 Hum. Rts. Dialogue 5, 6 (2000).

206. Id.

207. Chinkin, supra note 149 , at 144 .

208. Celina Romany, Black Women and Gender Equality in a New South Africa: Human Rights Law and the Intersection of Race and Gender, 21 BRoOK. J. INT'L L. 857 (1996); Hope Lewis, Between Irua and "Female Genital Mutilation": Feminist Human Rights Discourse and the Cultural Divide, 8 HarV. Hum. Rts. J. 1 (1995); see Isabelle Gunning, Arrogant Perception, World Traveling and Multicultural Feminism: The Case of Female Genital Surgeries, 23 Colum. Hum. RTs. L. Rev. 189 (1992) for an explanation of the ways in which North and South NCOs can have different perceptions of an issue and accord it different weight.

209. Chinkin, supra note 149 , at $144-45$. 
Apart from states, INGOs, and NGOs, other actors in the world of human rights standard-setting are individuals and institutions from the world of academia. These include renowned academics and jurists, policy think tanks, and the media. Individual thinkers and writers have also been influential players in the process. Although the media is not a direct participant in the norm-setting process, the exposure that a particular issue receives may make it a priority within UN circles. A case in point was the media coverage of both the Yugoslav and Rwanda genocides in the early to mid-1990s, a spotlight that shamed powerful states and pushed them to establish war crimes tribunals. The result was a development in the law and standards that relate to international criminal law, universal jurisdiction, war crimes, genocide, rape, and crimes against humanity.

\section{The Deficit of Democracy}

The deficit of participation is closely linked to the deficit of democracy in the world of IGOs, particularly within the United Nations. The post World War II order promised, in the words of the UN Charter, to "reaffirm faith in fundamental human rights, in the dignity and worth of the human person, in the equal rights of men and women and of nations large and small."210 But the Charter equivocated on the principle of sovereign equality when it made the Security Council, the key and most powerful organ of the UN, the exclusive club of the five major powers of the day. ${ }^{211}$ The General Assembly, the most representative and democratic of UN organs, was only given recommendatory powers, in effect reducing it to a talking shop and rubber stamp. ${ }^{212}$ It is remarkable to note that democracy, the noble ideal on which the UN was ostensibly founded, was also, paradoxically, its first casualty. The structures of the United Nations, which are today regarded as obsolete, have come under increasing attack. ${ }^{213}$ There is pressure for a radical restructuring of the United Nations to address the deficit of democracy within it. ${ }^{214}$

States do not have equal voices within the United Nations. The permanent members of the Security Council--the United States, China, France, United Kingdom, and Russia-wield enormous power in the United Nations system. Russia and China are less powerful even within the Security Council,

210. UN Charter, supra note 11, prmbl.

211. Id. Ch. V.

212. Id. Ch. IV.

213. MARTIN, supra note 199, at 20.

214. José E. Alvarez, The Once and the Future Security Council, 18 WASH. Q. 2, 3 (1995). 
which is dominated by the US, UK, and France. ${ }^{215}$ The powers of states are graduated according to their wealth, military power, size, and geographic location. These factors determine the influence and clout that states possess and can deploy to advance their interests within the UN. Thus, the United States and the European Union countries dominate the UN, although large but relatively poorer states like China, India, South Africa, and Brazil have sought more influence.

As a general rule, non-Western states lack power within the United Nations system. Their voices tend to be small and muted and their effect on standard setting processes less remarkable. Many African, Middle Eastern, and Asian states have traditionally been viewed as either unenthusiastic or opposed to intrusive human rights standards and mechanisms. Their voices in standard-setting bodies-especially in the area of civil and political rights-are regarded generally as unhelpful or obstructionist. This image of the South is changing although the stereotype persists. Many states in the South, such as Senegal, South Africa, Caribbean, and virtually all of Central and South America, are today more inclined to support or initiate new human rights standards. A growing number of states from Sub-Saharan Africa are also inclined to support such standards. This is a direct result of growing openness and the introduction of political democracy in these countries. The United States stands alone as a paradox among the industrial democracies in its opposition to the development of human rights standards. These trends have been confirmed in the adoption of recent instruments such as the Optional Protocol to CAT and the Declaration on Human Rights Defenders. The human rights-friendly states in the South have joined European states, including those in the former Soviet bloc, to form a lobby for human rights in IGOs. This new coalition of states is not faithful to the traditional North-South divide.

This new coalition of Northern and Southern states has its limits. It suffers from the constraints of ideology. States from the South only seem to

215. Michael Ignatieff has captured this Western domination of the UN Security Council and human rights in an unambiguous language:

[S] ince 1989, there has been a single human rights culture in the world, and nothing stands in the way to defy its moral imperium. Russia and China no longer have the power to do anything but deny Security Council approval to Western coalitions of the willing. Their veto power may deny legitimacy to actions by coalitions of the willing, but as the NATO operation in Kosovo shows, determined coalitions simply bypass the Security Council altogether. This momentous shift has combined with the coming of age of human rights advocacy from the grassroots in Western countries. . . But the impact of this shift has not necessarily been to the benefit of oppressed individuals, but rather to the benefit of the states which intervene in other states in the name of human rights.

Michael Ignatieff, Whose Universal Values? The Crisis in Human Rights, The Hague: Praemmium Erasmianum Essay 19 (1999). See also, Abdullahi An-Na'im, NATO on Kosovo is Bad for Human Rights, 17 NetH. Q. Hum. RTs. 229 (1999). 
have more democratic space in IGOs when they support or initiate human rights standards that fall in line with the national interests and legal traditions of the North. Standards that are directed at the economic inequities of the global order have not gone far, nor have Southern states been able to find enough democratic space and support for these initiatives. The right to development is perhaps the most poignant manifestation of this chasm between the two blocs. Southern states have not helped themselves either. Many are still undemocratic and unrepresentative of their own societies and cannot, as such, advance or convey the democratic aspirations of their peoples in the $1 G O$ world. Nor can they, because of their distaste for civil society, tap into the reservoir of NGO resources. This compounds the deficit of democracy and makes it more difficult for traditionally marginalized states from the South to become more effective players within ICOs.

Non-state actors, especially NGOs, are also mired in problems related to the deficit of democracy in the context of their work within IGOs. The nature of NGOs is at the center of this question. It is important to state, categorically, that NGO participation in IGO standard setting does not necessarily answer the democratic challenge or enhance transparent, democratic, and representative decisionmaking. NGOs can often deliberately subvert democracy because NGOs are not, by their nature, generally representative. They are self-appointed, usually individual-driven, and run by an individual or a small elite group that solely determines the agenda and the priorities for the organization. Similarly, they are usually not elected and do not normally practice internal or institutional democracy or transparency. ${ }^{216}$

Domestic NGOs often present themselves as the voice of the people at the national level. This is the basis of their claim for legitimacy. They present themselves as the conscience of the people, battling the behemoth on behalf of the poor and powerless. INGOs have sought to replicate this model at the international level. Since the dawn of the human rights movement, INGOs have insisted that they belong at the table of international governance. States and IGOs have, in turn, ceded ground to NGOs, lending credence to their claim of legitimacy on the implausible argument that they are the voices of the people. Even as states retain supremacy in the norm creation fora, they have in effect conferred legitimacy on NGOs by treating them as partners in international governance. A Canadian official confirmed this view when he noted during negotiations on the Landmines Convention that INGOs "have been the voice saying that government belongs to the people, and must respond to the people's hopes, demands and ideals." ${ }^{217}$ Have NGOs,

216. Riva Krut, Globalization and Civil Society NGO Influence in International Decision-Making, UNRISD, Discussion Paper 83, at 1 (Apr. 1997), available at http://www.unrisd.org/unrisd/ website/document.nsf/0/87428A38D3E0403380256B650043B768?OpenDocument.

217. Canadian Foreign Minister Axworthy, quoted in Anderson, supra note 189, at 91. 
and particularly the INGOs that dominate the human rights standard-setting processes, overreached? Do they claim and seek a legitimacy they do not have, and can never acquire?

It must be noted the few INGOs that dominate the IGO scene are more than happy to wear the label of "international civil society" or "global civil society," terms that invoke and connote the image of the more representative, diverse, and grassroots-oriented domestic NGOs. This can be misleading. The so-called "international civil society" is therefore an unfortunate term as applied to INGOs because they are not the masses or conduits of the people. They are, as Kenneth Anderson states, "a vehicle for international elites to talk to other international elites about the things-frequently of undeniably critical importance-that international elites care about." It is a conversation that is horizontal, not vertical. Anderson notes emphatically that this horizontal dialogue, a kind of romance between INGOs and IGOs, has a "worthwhile, essential function in making the world-sometimes at least, a better place-but it does not reduce the democratic deficit." ${ }^{218}$ INGOs are effective pressure groups that lack democratic legitimacy. Anderson further notes:

[T] he far more typical international NGO of the kind whose favor and approval international organizations [ICOs] seek is much closer to the model of Human Rights Watch-a relatively small, highly professional, entirely elite organization funded by foundations and wealthy individuals in the Western democracies, and having no discernable base outside international elites. This is not to denigrate Human Rights Watch or the vital work it does, but it would be the first to declare that its legitimacy is not based on democratic roots among the masses but on its fidelity to its own conception of the meaning of international human rights. ${ }^{219}$

In other words, INGOs like Human Rights Watch are accountable only to themselves and their wealthy donors. Even Amnesty International, which unlike Human Rights Watch is a member organization, cannot claim to be very different. Its "membership comes mostly from wealthy countries, and its membership even in those countries tends to be educated and at least middle class." ${ }^{220}$ IGOs tend to favor INGOs like Human Rights Watch-rich, expert-laden, highly professional, and powerful-over the poorer and relatively under-resourced domestic Southern NGOs. However, the latter are more likely to be connected to the people. For this reason, the campaigns and concerns that are dear to INGOs tend to be more successful in terms of standard setting. These attitudes and structural relationships do not reduce-but instead tend to enhance-the democratic deficit within IGOs.

218. Id.

219. Id.

220. Id. 


\section{Language: Content and Implementation}

Virtually all advocates and organizations in human rights now support creating binding human rights norms. ${ }^{221}$ The ideal has been to strive for an instrument that is both acceptable to states and which the states will feel obligated to implement. However, states want norms that will exact the lowest cost on their sovereignty. This requires a highly skilled balancing act by states because no state wants to be perceived as gratuitous opponents of human rights.

The power of human rights rhetoric is so great that opposition to human rights standards is usually couched in terms of legitimate state interests. However, some of the excuses are transparent. When it became politically incorrect to openly reject human rights standards, many undemocratic, authoritarian, poor states took cover behind a plea of the scarcity of resources and lack of trained personnel to carry out implementation. States and ICOs, on the one hand, and NGOs, on the other, have generally worked at cross-purposes. The former are more likely to accept soft-law, less binding instruments whereas the latter want to maximize the impact of human rights standards through the adoption of concise, binding, and effective instruments.

There would be no purpose to developing standards, but never enforcing or implementing them. The process of setting standards, which is universal in the sense that it formally takes place within the United Nations, implies a collective will greater than that of an individual state to see those norms respected. This paradox suggests that states, IGOs, and non-state actors have to work through complex and delicate negotiations to establish a balance that each can claim as a success. These compromises start at the standardsetting level and are not completed until processes and institutions for monitoring, encouraging, or ensuring the implementation of standards are reached. Language--its use and precise meaning - is critical to the creation of norms and their implementation.

\section{E. The Relationship Between Norms and Institutions}

There is a pervasive belief in academic and activist circles that UN institutions charged with the monitoring and enforcing human rights standards are largely ineffective, if not impotent. ${ }^{222}$ However, it is impossible to imagine

221. Interview with Bertrand Ramcharan, then Deputy High Commissioner for Human Rights, Geneva, Switzerland (4 Dec. 2002).

222. Makau Mutua, Looking Past the Human Rights Committee: An Argument for De-Marginalizing Enforcement, 4 Buff. Hum. Rrs. L. Rev. 211 (1998). 
the normative human rights regime without its institutionalization in the UN Charter and the various treaty bodies. This would leave national governments with the voluntary discretion to police themselves and to decide what and how to enforce human rights standards. In theory, one might argue that states could rise to the challenge, but this view ignores the motivation states would have to renege on their promises and backtrack on enforcement. ${ }^{223}$ This would happen for the simple reason that states do not like to be constrained. For this reason, civil society and domestic NGOs, at the national level, and IGOs and INGOs at the international level, are necessary to pressure, monitor, cajole, and encourage states to honor their human rights obligations. In short, human rights norms only make sense when anchored in institutions.

This intrinsic relationship between norms and institutions makes the design of UN institutions in which human rights norms are anchored an integral part of the standard setting process. Standards are not set in the abstract without thought being given to how they will be implemented, enforced, and realized. Universal human rights standards must be taken down to the national level, where they will ultimately make a difference. The process of standard setting must adopt a legal realist approach and relate what is produced to how it is implemented, otherwise it is impossible to gauge the effectiveness of norms. ${ }^{24}$ It is at this intersection-where norms and institutions meet-that most of the contestation over the scope, depth, and authority of the human rights regime has taken place.

Two types of institutions at the UN pose different questions for the setting of standards and their implementation. Although both types either set or develop norms and then oversee their implementation or enforcement, UN Charter-based bodies, like the UN Human Rights Council, and treaty bodies, like the CEDAW Committee or the UN Human Rights Committee, are confronted with different challenges. First, Charter-based organs like the Human Rights Council are the quintessential IGO. Each of its forty-seven member states have interests beyond human rights that they will seek to protect through the Council, despite the fact that it replaced the more politically charged Commission.

In the UN hierarchy, Charter-based organs can arguably be regarded as superior to treaty bodies for a number of reasons. It is the Charter organs, principally the Council, that would draft and vet human rights treaties before sending them to the General Assembly for approval and adoption. The Council and General Assembly demarcate and delimit the scope and

223. Interview with Abdullahi An-Na'im, Professor, Emory University School of Law, Atlanta, Georgia (27 Nov. 2002).

224. Interview with Henry J. Steiner, Director, Human Rights Program, Harvard Law School, Cambridge, Massachusetts (29 Nov. 2002). 
depth of human rights obligations that states may undertake. The two organs therefore determine the powers that treaties confer on the treaty bodies, such as the CEDAW Committee, in the exercise of their oversight, monitoring or enforcement functions. The ECOSOC, another Charter organ, may in situations where an instrument does not provide for a treaty body, as is the case with the ICESCR, set up such a body. 225

It is through Charter organs that states and IGOs retain control over the nature of human rights standards and the mode of their enforcement. In formal terms, standard setting is carried out within IGOs, not the treaty bodies, although the reality is more complex. Through their interpretive powers, treaty bodies have made significant contributions to human rights. Many treaties tend to be either broad or vague, so it has fallen on treaty bodies to elaborate, clarify, and elucidate standards by more clearly defining their meaning and the scope of states' obligations. Without a doubt, treaty bodies serve not merely an interpretive function, but rather, in effect, engage in standard-setting.

\section{F. Standard Setting and Implementation in Practice}

The UDHR was thought to be the document that would precede the more detailed elaboration of the human rights obligations of states in a binding treaty. Initially, there was hope that just such an instrument would immediately follow the UDHR. However, Cold War conflicts and tensions between the United States and the West, on the one hand, and the Soviet Union and the socialist bloc, on the other, brought these noble expectations to a screeching halt. Disagreements about models of political society and economic philosophies combined with sovereignty concerns to seriously qualify the major powers' commitment to human rights.

The business of standard setting would henceforth be a struggle over ideology, philosophy, culture, and sovereignty. The first casualty of these disagreements was the push for a single human rights treaty. The project started in 1949, but it was abandoned in 1951 when it became clear that the Western-dominated Commission on Human Rights would only agree to two separate treaties. One treaty was to be based on civil and political rights and the other on economic, social, and cultural rights. ${ }^{226}$ The nature

225. In 1987, ECOSOC set up the Committee on Economic, Social and Cultural Rights, even though it was not provided for in the ICESCR. Article 68 of the United Nations Charter empowers ECOSOC to "set up commissions in economic and social fields and for the promotion of human rights." See Thomas Buergenthal, Dinah Shelton, \& David Stewart, International Human Rights 69-70 (2002).

226. Annotations on the Text of the Draft International Covenants on Human Rights, Report by the Secretary-General, U.N. GAOR, 10th Sess., Annex 50, I 9, U.N. Doc. A2929 (1955). 
of the norms and their implementation measures were two critical issues facing the Commission on human rights as it sat to draft the two covenants. The West argued that civil and political rights, which are the staple of its liberal state, were enforceable, justifiable, absolutely fundamental, and, therefore, immediately applicable. ${ }^{227}$ These rights were said to be individual claims against the state, a prohibition of unlawful actions against the state, for which the state was not required to take any positive action. The West contended that economic, social, and cultural rights were claims on the state, and could only be implemented progressively, requiring positive action by the state. ${ }^{228}$

This dichotomous view - which regrettably has been an enduring legacy of the human rights corpus-masked the West's fear that human rights standards and obligations would be enforced against free market economic structures and policies. Even so, the West would not have argued for two separate documents if no implementation mechanisms were contemplated. The ICCPR provided for the Human Rights Committee, regarded as one of the more credible treaty bodies, to oversee its implementation. However, the ICESCR was left without a treaty body and only provided for the submission of periodic reports to the UN Secretary-General and ECOSOC, a largely meaningless oversight function. ${ }^{229}$

The differences in the implementation and oversight of the two covenants are made all the more stark by the normative distinctions between them. These two documents are written in different language. The obligations in the ICCPR are generally definitive and clear. The ICESCR, on the other hand, is laden with broad and sometimes hortatory language. Specifically, the ICCPR grants individuals rights against the state. Typical of this approach are these phrases used in the ICCPR: "no one shall be" or "any one who." This language sharply contrasts with the ICESCR, which placed obligations on states with terms such as "states parties recognize the rights of everyone to" or "states parties to the present covenant undertake to." The other key difference between the covenants is the permissive language and the equivocation of the ICESCR, which is absent in the ICCPR. The ICESCR obligations are open-ended, without performance targets. In the ICESCR, a state is only required to fulfill its obligations "to the maximum of its available resources, with a view to achieving progressively the full realization of the rights." ${ }^{230}$

\section{Id. I 9.}

228. Id. See also Philip Alston \& Gerald Quinn, The Nature and Scope of States Parties' Obligations Under the International Covenant on Economic, Social and Cultural Rights, 9 Hum. RTs. Q. 156 (1987).

229. ICESCR, supra note 63, pt. IV. In 1987, ECOSOC established the Committee on Economic, Social and Cultural Rights to oversee the implementation of the ICESCR.

230. Id. art. 2(1). 
This vacuous language has thus far undermined genuine progress in the achievement of economic, social, and cultural rights.

The ICCPR was among the first general scope human rights instruments to create a treaty body to oversee its implementation. Its provision for the Human Rights Committee was therefore a remarkable achievement at the time. States had never before authorized such a body to supervise them in the implementation of international human rights standards. The Human Rights Committee was charged with two basic functions: (i) reviewing performance by examining state reports, and (ii) issuing general comments, that is, developing an interpretive jurisprudence of the ICCPR. ${ }^{231}$ The Optional Protocol to the ICCPR added a third function to the Human Rights Committee. It authorized the Committee to receive and issue opinions, known as "views," on the petitions of individual victims. ${ }^{232}$ Although comparative analyses show that the Human Rights Committee remains one of the most effective of the seven treaty bodies, ${ }^{233}$ a critical appraisal of its structure and powers indicate that states did not want to couple a normatively strong instrument with an intrusive enforcement body. States allowed members of the Human Rights Committee to be independent experts, but denied the organ a quasi-judicial character and made the individual petition procedure entirely optional. This left the Human Rights Committee with only one compulsory role- that of studying and commenting generally on state reports. ${ }^{234}$

Since 1966, when the first two human rights covenants were adopted, standards on most human rights concerns have been set in place. The process of standard setting was then-and still is today-contentious, lengthy, and laborious. This may be the age of rights, where the rhetorical power of sovereignty is no longer what it once was, but human rights standard setting are still an uphill task. There are indications that it has become even more difficult over the last decade to push for new standards, at least in treaty form. State and IGO concerns over sovereignty, culture, ideology, and power are as present today as they were before 1966. Since then, the script of the drafting of the ICCPR and ICESCR has largely been generally followed with minor only variations. The negative legacy of the first two covenants

231. ICCPR, supra note 63 , art. 40.

232. Optional Protocol to the International Covenant on Civil and Political Rights, adopted 16 Dec. 1966, G.A. Res. 2200 A (XXI), U.N. GAOR, 21 st Sess., Supp. No. 16, U.N. Doc. A/6316 (1966), 999 U.N.T.S. 171, (entered into force 23 Mar. 1976), reprinted in 6 I.L.M. 383 (1967).

233. The other six treaty bodies are the Committee on Economic, Social and Cultural Rights, the Committee on the Rights of Children, the Committee on the Elimination of Racial Discrimination, the Committee Against Torture, the Committee on the Elimination of Discrimination Against Women, and the Committee on Migrant Workers.

234. Torkel Opsahl, The Human Rights Committee, in The United Nations and Human Rights, supra note 19, at 371. See also Dominic McGoldrick, The Human Richts Commitree (1991). 
continues to persist today. States and IGOs manipulate language to blunt, soften, or evade effective human rights standards.

The fate of the right to development underscores the reluctance by states and IGOs to work for a definitive, powerful, and clear language of obligatory norms. There is nothing concrete in the UN Charter or the UDHR that gives specificity or direction on the right to development, although there are references to the need for international solidarity to economic and social problems. ${ }^{235}$ The UDHR also refers to an international order in which the rights in it can be realized. ${ }^{236}$ Proponents rely on these general provisions as the moral and legal basis of the right to development. Since 1977, when the UN Commission on Human Rights recognized the right to development, many powerful states, IGOs, international financial institutions, academics, and human rights activists have challenged it. Active opposition and lack of support from powerful individuals and interests have crippled the right to development. The failure to develop convincing, credible, and clear language to talk about this right has marginalized discourse on it. ${ }^{237}$ Despite many reports by IGOs, there is no agreement on the meaning of the right or what the practical consequences of its recognition might involve. The Declaration of the Right to Development, which is written in a high-sounding, rhetorical, and vague language, is not helpful. Norms cannot be effective unless they are unpacked into clear components, spelling out obligations and rights, and identifying the path to their implementation at the national level. These factors, among others, have conspired to make the right to development impotent. ${ }^{238}$

Language can be an ally to the standard setter when it is used carefully and when states do not see it as creating new obligations or establishing new law. This is the apparent reason for the success of the Guiding Principles on Internal Displacement. States and IGOs have rushed to embrace the Guiding Principles, which suggests that they are crafted in a language that is acceptable to them. It bears restating that the Guiding Principles, which

235. UN Charter, supra note 11, arts. 55, 56 .

236. UDHR, supra note 15 , art. 28 ,

237. Some of the most biting attacks on the right to development have been launched by prominent Western academics. Stephen P. Marks, for instance, has argued that third generation human rights, of which the right to development is the most prominent, are "too vague to be justifiable and are no more than slogans." Jack Donnelly, an opponent of group or collective rights, has been more critical, declaring the right to development "fallacious," "bizarre," "misguided," and "dangerous." See Stephen Marks, Emerging Human Rights: A New Generation for the 1980s?, 33 RutGers L. Rev. 435, 451 (1981); Jack Donnelly, In Search of the Unicorn: The Jurisprudence and the Politics of the Right to Development, 15 CAL. W. INT'L L. J. 473, 482 (1985). With virtually no prominent defenders, the right to development lacks elaboration and has remained murky.

238. Interview with Steiner, supra note 224. See generally Margot E. Salomon, \& AruUn Sencupta, The Right to Development: Obligations of States and the Right of Minorities and Indigenous Peoples (2003). 
are not a declaration or a resolution, do not technically constitute soft law because they were neither negotiated by states nor produced by an IGO. Therefore, they lack the authority that comes from the resultant consensus or adoption. ${ }^{239}$ In a sense, the Guiding Principles are redundant and for that reason do not really threaten states. Some states see them as merely providing guidelines for the application of existing law. ${ }^{240}$ The genius of the Guiding Principles is that they combine in clear, detailed, and unambiguous language the restatement of existing legal obligations with the seemingly harmless form of the instrument-neither a treaty nor a declaration. Walter Kälin expressed ambivalence on the form of the instrument and is more interested in whether the Guiding Principles will become effective. It does not matter to him whether they use the language of the law or take the legal form. ${ }^{241}$

Analyses of the use of language in standard setting show a link between language and the modes of implementation or enforcement of an instrument. This is true for all instruments, whether or not they enjoy strong support from states and IGOs. The typical example is CEDAW and its committee in which an ambitious instrument was coupled with a weak treaty body. Relatively or potentially strong functions in treaty bodies may be made optional to avoid the deep penetration of the state. The only clear exception to this rule is the CRC where an effective, innovative, aggressive, and open committee oversees a strong instrument. ${ }^{242}$ That is why the CRC has succeeded beyond the expectations of its sponsors. ${ }^{243}$ This is explained by the fact that the CRC is the only human rights instrument that was almost entirely the product of NGOs. Hence, its departure from the norm. Otherwise, left to their own devices, states will always opt high rhetoric human rights instruments with little teeth.

\section{CONCLUSIONS}

\section{A. What is the Future of Standard Setting in Human Rights?}

Even with historic conceptual and institutional breakthroughs, a lot remains to be done to secure human dignity. Although human rights standards

239. Recent Commentakies on Guiding Principles, supra note 42, at 7-8.

240. Deng, The Global Challenge of Internal Displacement, supra note 122, at 147.

241. Recent Commentaries on Guiding Principles, supra note 42, at 10.

242. Gerison Lansdown, The Reporting Process Under the Convention on the Rights of the Child, in The Future of Human Rights Treaty Monitoring 113 (Philip Alston \& James Crawford eds., 2000).

243. Interview with David Johnson, Office of the High Commissioner for Human Rights, Geneva, Switzerland (4 Nov. 2002). 
have been set in virtually all areas that touch on human dignity, normative gaps and weaknesses still exist in many areas. New normative frameworks are needed in some areas, while in others they must be elaborated and strengthened. Standard setting is a dynamic process that must respond to a rapidly changing globe and challenges that come with the emergence of new problems and conditions. The argument that the era of standard setting is over is not only mistaken, but dangerous.

The setting of human rights standards is not a static process. The conditions of humanity that human rights standards seek to safeguard and promote are evolving concepts. New conditions of oppression and powerlessness are forever being discovered, and new challenges are constantly emerging. For example, the gay rights movement and the campaign for the rights of people with disabilities were unthinkable just a few decades ago. The current US war on terror has similarly thrown up new obstacles to established norms. There is no doubt that these and many other issues require a normative response. The struggle for and definition of human freedom and development is a continuous and evolutionary process. These issues require unceasing vigilance, revision, re-evaluation, deepening, and re-definition. Broad norms and standards must be unpacked, broken down, elucidated, revised, and may even need to be rejected and replaced by new and different standards. The scope, reach, and content of norms must be comprehensible to their beneficiaries, as well as to those who bear the responsibility for their implementation. Vacuous, rhetorical, and vague standards accomplish little.

To be effective, standards must have a clear path for their implementation and enforcement. This is an area of weakness. Institutions that are responsible for the promotion and protection of human rights standards-states and IGOs-are largely perceived by NGOs as reluctant, unwilling, unable, or ineffectual actors. They are seen as interested mostly in blunting the bite of human rights to safeguard state sovereignty. The effect of human rights must be translated at the national level, so municipal institutions that safeguard basic rights are critical to enforcement. Judiciaries, national human rights institutions, bar associations, NGOs, police and security apparatuses, and legislatures must be in the frontline to entrench, deepen, promote, and protect human rights. However, only human rights NGOs among these institutions can usually be relied on to advance the human rights agenda with vigor, honesty, and a healthy disinterest. Human rights norms must be internalized by states in their legal and political orders to be effective.

The relationship between universal norms and IGOs, on the one hand, and national norms and institutions of enforcement, on the other, must be streamlined and harmonized to enhance their inter-penetration. This vertical relationship between international and national processes is critical for the domestic internalization of human rights norms. Without this relationship, states cannot cultivate a human rights culture to police themselves. It is through 
the experience gained in enforcement by national institutions that NGOs, IGOs, and states can identify normative gaps that need to be addressed and institutional weaknesses that must be corrected. In other words, the national space is the anvil on which human rights norms are unpacked and forged. It is the crucible in which human rights must be grown. The lessons gained from this interpenetration must inform the future of standard setting and the work of rectifying institutional weaknesses in implementation.

\section{B. The Quest for Standards in Economic and Social Questions}

The call for new standards in human rights has been opposed by some influential academics and large INGOs, unless such standards were consistent with the mandates of these INGOs. These individuals and groups oppose what they see as a proliferation of claims using the language of rights. They are skeptical of so-called second and third generation rights--economic, social, and cultural rights, as well as group or peoples' rights, such as the right to development-which they think inflates the category of rights, deflates the power of the human rights language, and dilutes the potency of the human rights movement. To them, the human rights movement should focus on a narrow mandate, usually civil and political rights.

The mandates and work of Amnesty International and Human Rights Watch, the two largest INGOs, have traditionally reflected this worldview, although that is slowly changing. ${ }^{244}$ Since 1996, Human Rights Watch adopted a policy of addressing economic, social, and cultural rights, but only if their violation was related to its central mandate of protecting civil and political rights. ${ }^{245}$ This concession by Human Rights Watch to marginally expand its mandate came only after relentless criticism from the South threatened its credibility and effectiveness.

Amnesty International has acknowledged its own role in the historical rejection of economic and social rights by the West. Amnesty, with a mandate geared primarily to civil and political rights, has been part of this imbalance. The very success of the organization in building a worldwide membership and raising concerns among a wide public has been a factor in focusing attention on civil and political rights. Amnesty is now engaging

244. Peter R. Baehr, Amnesty International and its Self-imposed Limited Mandate, 12 NETH. Q. Hum. Rts. 5 (1994); Human Rights Watch, Human Rights Watch World Report 2000, at vii (2000).

245. In September 1996, Human Rights Watch abandoned its opposition to economic and social rights and adopted a limited and qualified policy whereby it would monitor compliance with the violations of the ICESCR, but only so long as they touched on the ICCPR. See Human Rights Watch, Human Rights Watch's Proposfo Interim Policy on Economic, Social, and Cultural. Righrs (30 Sept. 1996). See also Mutua, The Ideology of Human Rights, supra note 153, at 619, n.107. 
in broader human rights debates and seeks to promote the full spectrum of human rights in its campaigns and human rights education activities. Decisions taken by the 1997 International Council Meeting affirmed the need to explore ways of raising awareness of the full range of human rights, to provide more economic and social context in Amnesty International's reporting, and to make greater efforts to promote international standards and mechanisms protecting economic and social rights. ${ }^{246}$ Amnesty International now acknowledges that economic and social rights cannot be divorced from other human rights because of the consequences of globalization. It notes the protection of economic and social rights by NGOs is important particularly because of the failure of governments to protect citizens from the negative consequences of globalization..$^{247}$

While this is welcome news from influential actors in the human rights movement, both Amnesty and Human Rights Watch symbolize a negative legacy in economic and social rights. The initial decision by Human Rights Watch to include these rights, albeit marginally, sounded painful and extracted. Amnesty International and Human Rights Watch are the two most powerful non-state actors in the field of human rights. As such, their embrace of economic and social rights is important and should not be half-hearted if it is to be meaningful. In a radical departure, Irene Khan, the incumbent Al Secretary General, has led an admirable push for a more inclusive view of human rights.

Civil and political rights enjoy a normative superiority that is the envy of the advocates of economic and social rights. There is virtually no domestic jurisprudence, obligatory policies, or mandatory practices in most states on economic and social rights. States and IGOs do not see the development and implementation of these rights as an obligation. Many see them as desirable goals, not rights. Even when they see them as either obligations or rights, they relegate them to other concerns and overlook them. In 1993, the ICESCR Committee noted that "states and the international community as a whole continue to tolerate all too often breaches of economic, social and cultural rights" and attributed this impotence to "a reluctance to characterize the problem that exists as gross and massive denials of economic, social and cultural rights. ${ }^{248}$ Part of the problem is in the ICESCR itself, which is unclear on the nature of the obligations on states. Although the ICESCR Committee has attempted to clarify, unpack, define, and give guidance to

246. Amnesty International, Annual Report 1998 (1999), available at http://www.amnesty.org/ ailib/aireport/ar98.

247. Id.

248. Committee on Economic, Social and Cultural Rights: Statement to the World Conference on Human Rights, U.N. ESCOR, Comm. on Econ., Cult. \& Soc. Rts., I I 5, 7, Annex III, U.N. Doc. E/1993/22 E/C.12/1992/2(1993). 
the covenant's provisions and the obligations of states, its work has gone largely unnoticed. The Committee has failed to spark INGO activism and insightful commentary from influential academics.

NGO, and particularly INGO, activism and focus on economic and social rights are necessary for their normative development and clarification of the obligations of states. The negative consequences of globalization give these rights an urgency that must not be compromised by pretexts and excuses. NGOs must now approach economic and social rights-the next frontier in human rights-with the same zeal that drives them in their advocacy for civil and political rights. Substantial normative victory can now be declared in civil and political rights, a fact that should release some of the energy, resources, and skills of NGOs to the other, equally important, cannon of the human rights corpus-economic and social rights. It is only through the vitality of NGOs that IGO inertia in these rights can be reversed.

It is in the elaboration of standards in the field of economic and social rights that the Declaration on the Right to Development will come to life because the jurisprudential and normative elements pertinent to it are embedded in questions and challenges of globalization, markets, and economic underdevelopment. The ICESCR and the Declaration should be read as sister instruments, and work on their elaboration and implementation should be seen as intrinsically related. The central questions that the Declaration on the Right to Development sought to address-economic powerlessness, underdevelopment, and exploitation-can be addressed in tandem with the ICESCR.

\section{The Need for a Normative Framework on Disabilities}

Human rights instruments can be general, like the UDHR, or thematic, like the ICCPR or CEDAW. However, all human rights instruments are based on the principle of equal protection and non-discrimination, which are the pre-eminent norms of the human rights movement. The existence of general scope human rights documents, in which everyone is protected, such as the ICCPR, does not obviate the need for a specific instrument targeted at a particular class of people or problem. That is why the female gender, which is guaranteed by all the rights in the ICCPR, still needs its own specific normative framework to address the particular problems and conditions that attach to it by virtue of its difference. The same is true with racial groups, minorities, indigenous peoples, workers, children, and other classes, categories, or groups with shared historical, ethnic, religious, social, linguistic, cultural, or other characteristics. It is only by recognizing these differences and specifically addressing them that society can ensure the victims equal protection. This is the reason why disabled persons have sought a normative framework to address their plight. 
The protection of the rights of persons with disabilities is a recent development in most societies. For millennia, people with disabilities have suffered the most destructive of treatments, including murder, banishment, exclusion, and discrimination. The United States enacted a law specific to persons with disabilities. ${ }^{249}$ South Africa went even further and entrenched the protection of persons with disabilities in its 1996 Constitution. ${ }^{250}$ There is a growing awareness internationally that states and institutions ought to pass laws and create policies to protect persons with disabilities. NGOs that advance the cause of persons with disabilities have sprung up in most states.

In the last two decades, the United Nations has taken some modest steps to make persons with disabilities more visible in the human rights field. The UN declared 1981 the International Year of Disabled Persons. ${ }^{251}$ In 1982, the UN adopted the World Programme of Action Concerning Disabled Persons. ${ }^{252}$ In 1987, a meeting of experts declared these steps inadequate and recommended that the UN adopt a treaty on the subject. In 1993, the UN General Assembly adopted the Standard Rules on the Equalization of Opportunities for Persons with Disabilities. ${ }^{253}$ In 1994, the UN appointed Bengt Lindqvist, a former Swedish cabinet minister, Special Rapporteur on Disability. In September 2001, President Vicente Fox of Mexico gave official voice to calls by disability INGOs when he proposed that the UN elaborate and adopt a convention on disabilities. In response, the UN General Assembly established an Ad Hoc Committee to work on the question of a convention. In June 2002, the Mexican government hosted, with UN assistance, an inter-regional expert group meeting to discuss the elaboration of a disabilities convention.

Advocates for disability rights, including Mexico, were convinced that only a binding convention would be an effective method for protecting the rights of persons with disabilities. They correctly argued that the soft law measures taken by the UN, including the appointment of a Special Rapporteur, had borne little fruit beyond raising the visibility of disability concerns. Lindqvist, who served as the Special Rapporteur until December 2002, wanted the proposed convention based on existing human rights instruments and the principles spelled out by the ICESCR Committee in 1994. ${ }^{254}$ In October 2002, the Special Rapporteur applauded the initiative and leadership of Mexico

249. Americans with Disabilities Act, Public Law 101-336, 26 July 1990, 104 Stat. 327, 101 st Congress.

250. S. Afr. Const., ch. $2, \S 9(3)$.

251. International Year of Disabled Persons, adopted 16 Dec. 1976, G.A. Res. 31/123, U.N. GAOR. 31st Sess., Agenda Item 03, U.N. Doc. A/RES/31/123 (1976).

252. World Programme of Action Concerning Disabled Persons, adopted 3 Dec. 1982, G.A. Res. 37/152, U.N. GAOR, 37th Sess., U.N. Doc. A37/351 (1982).

253. Standard Rules on the Equalization of Opportunities for Persons with Disabilities, G.A. Res 48/96, U.N. GAOR, 48th Sess., U.N. Doc. A/Res/48/96 (1993).

254. CESCR General Comment NO. 5, adopted 9 Dec. 1994, U.N. Hum. Rts. Comm., 11 th Sess., U.N. Doc. E/1995/22 (1994); Bengt Lindqvist, Some Thoughts on the Elaboration of a Disability Convention, WorldEnabte (5 June 2002), available at http://www.worldenable.net/mexico2002. 
in the drive for a convention, but he warned that there was resistance and opposition from a large number of states. ${ }^{255} \mathrm{He}$ outlined three reasons that should be used to bring reluctant states on board. First, existing human rights instruments did not address the plight of persons with disabilities, which the proposed convention would. Second, a special convention would give status and visibility to disability rights, which other thematic treaties had done. Finally, only a special convention would provide an effective mechanism to monitor the implementation of disability rights. ${ }^{256}$

Given all these activities, the momentum for a convention on disabilities picked up. Domestic NGOs, INGOs, and the International Disability Alliance (IDA)-a coalition of non-state actors came together to fast track a disability convention. ${ }^{257}$ The determined leadership of Mexico was instrumental in blunting reluctance or opposition to the convention from poorer states who lacked resources to address meaningfully the plight of persons with disabilities. Finally, on 13 December 2006, the General Assembly of the United Nations adopted the Convention on the Rights of Persons with Disabilities and the Optional Protocol to the Convention on the Rights of Persons with Disabilities. ${ }^{258}$ The Convention and its Protocol were put forward for signature by states on 30 March $2007 .{ }^{259}$ On the first day, the Convention was signed by a record eighty-one states, a seeming commitment to improve the lives of the estimated 650 million with disabilities worldwide. ${ }^{260}$ Regrettably, only one country-Jamaica-had ratified the Convention which needs twenty ratifications to enter into force. ${ }^{261}$ Ultimately, the language of the convention, the nature of the obligations of states, and the mechanisms for its monitoring and implementation will determine how quickly states ratify it so that it can enter into force. In the meantime, the convention's proponents must lobby, cajole, pressure, and push states to ratify. The successful campaign for the CRC should offer them valuable lessons. Disability rights are one of the last major equal protection issues in which the UN has now created treaty obligations on states.

255. Bengt Lindquist, All means All, Keynote speech by UN Special Rapporteur on Disability, Osaka Forum, Japan (Oct. 2002).

256. Id.

257. Aaron A. Dhir, Human Rights Treaty Drafting Through the Lens of Mental Disability: The Proposed Convention on the Protection and Promotion of the Rights and Dignity of Persons with Disabilities, 41 StANFord J. INT'L L. 181 (2005). The IDA is the leading NGO lobby group for a disability convention.

258. Convention on the Rights of Persons with Disabilities, G. A. Res. 61/106, U. N. GAOR, 61st Sess. (2007).

259. Id. art. 42.

260. Independent Rights Expert Calls for More Support for UN Treaty on Disabilities, U.N. News CeNTRE, 12 Apr. 2007, available at http://www.un.org/apps/news/story.asp?NewsID $=22196 \& \mathrm{Cr}=$ disabilities \& $\mathrm{Cr} 1=$.

261. Convention on the Rights of Persons with Disabilities, supra note 258, art. 54. 


\section{Other Candidate Issues for Standards}

It is difficult to predict today with precision what new human rights standards will be needed in the future. It is certain, however, that the quest for new standards or for the expansion, re-definition, and elucidation of existing standards will not end. Nor will fresh campaigns to institute new-or improve upon-monitoring, implementation, and enforcement mechanisms and processes. In short, standard setting is a dynamic, open-ended process. The only questions that remain open are the areas in which those standards will be set and the nature of the normative framework they will adopt. Still, on the horizon there is a silhouette of emergent concerns that should become more pressing with time. These include existing standards that need further elaboration, as well as new issues that are beginning to exert themselves on the conscience of humankind.

Women's rights is one area where existing standards and enforcement mechanisms require additional attention. It is only in the last two decades that the human rights movement has lifted the veil over women's rights. It is merely in the last decade in particular that many societies have started to recognize and address the stubborn and deeply embedded laws, practices, beliefs, customs, and structures that are the instruments for the victimization of women. The doctrines and practices of all religions-both major and minor-largely buttress negative views and practices against women. It is here that the human rights movement, including the women's rights movement, falters and struggles mightily to find effective and acceptable approaches for change. CEDAW, the key women's treaty, its Committee, the UN Special Rapporteur on Violence Against Women, and the 1995 Beijing Platform for Action are significant normative and institutional achievements in the struggle for women's dignity and development-but they are just a beginning. Women still remain seriously lacking in virtually all spheres of life in most countries. ${ }^{262}$

Existing standards on women's rights-and the corresponding duties on states-have to be clarified further, and more guided performance targets need to be established in order for them to be realized. More resources and energy must be applied to the translation of these standards at the ground level within nations. Universal monitoring and enforcement bodies, like the CEDAW Committee, may have to be reformed to make them more effective. ${ }^{263}$ At the normative level, more may have to be done in the vexed relationship between religious doctrine and practice and women's rights. The work of

262. Uniteo Nations Development Programme, Human Development Report 1993, at 25 (1993).

263. Mara Bustelo, The Committee on the Elimination of Discrimination against Women at the Crossroads, in The Future of Human Rights Treaty Monitoring 79, 81 (Philip Alston \& James Crawford, eds., 2000). 
Abdullahi An-Na'im, a scholar of Islam and human rights, who pursues the normative reinterpretation of holy text and Sharia to promote and protect the rights of women, will be indispensable in setting new or reforming existing human rights standards. ${ }^{264}$ This and similar scholarship should be the basis for more informed NGO normative activism within IGOs and states. Translating the normative and institutional gains of the last decade, including the Beijing Platform for Action, will require the refinement of standards or the creation of new ones to reach entrenched problems, obtain effective receptivity, and promote enforcement by individual states.

Terrorism is another international problem that has exerted pressure on human rights. The standard-setting universe appears to have contracted somewhat after the 9/11 suicide attacks and the US response to them. It has even been suggested that the human rights era may be over. Popular and scholarly commentary suggests that concerns about security and terrorism have pushed human rights further down the ladder of international concerns. ${ }^{265}$ Recent actions by a number of governments suggest that terror and security are now being used as a pretext to violate human rights or sharply qualify official support for them. ${ }^{266}$ There is no dispute that states have an obligation to protect those within their borders from violent attacks. However, the war against terror must not be used as a pretext to trample on human rights.

There must be proper balance between human rights and security concerns. This means that human rights NGOs and think tanks must lead efforts to establish a normative and policy relationship between human rights and the duty of states to protect civilians from violent attacks without compromising human rights. Existing UN instruments on terror and related questions were designed to prevent and punish terror, and not to deal with the relationship between terror and human rights. ${ }^{267}$ NGOs and IGOs ought to take a fresh look at this complex dilemma and suggest a normative framework to address it. It seems clear that new standards will have to be set to unravel the conflict between these two critical but conflicting questions. ${ }^{268}$

264. Abdullahi An-Na'im, Human Rights in the Muslim World, 3 Harvard Hum. Rts. J. 13 (1990); Abdullahi An-Na'im, State Responsibility Under International Human Rights Law to Change Religious and Customary Law, in Human Rights of Women: National and International. Perspectives (Rebecca Cook ed., 1994).

265. Michael Ignatieff, Is the Human Rights Ending?, N.Y. Times, 5 Feb. 2002, at A25.

266. International Council on Human Rights Polcy, Human Rights after September 11, at 19 (2002).

267. European Convention on the Suppression of Terrorism, opened for signature 27 Jan. 1977, Council or Europe, CETS No. 90 (entered into force 4 Aug. 1978), 15 I.L.M. 1272 (1976); International Convention Against the Taking of Hostages, U.N.G.A. Res. 34/146 (XXXIV), 34 UN GAOR, Supp. (No. 46) 245, U.N. Doc. A334/786 (1979), 18 I.L.M. 1456 (1979).

268. Interview with Ramcharan, Supra note 221. 
The last major emerging issue that requires international standards is sexual orientation, another equal protection problem. Patriarchy and heterosexism are the dominant assumptions of all major legal, religious, social, political, economic, and cultural traditions. The national state and the international legal orders are based on these assumptions. Discrimination, exclusion, neglect, and abuse of gays and lesbians are common to most societies. Anti-homosexual attitudes and practices have historically been given expression in the law of virtually all states. However, in the past several decades gay rights movements have cropped up at the national and international levels. These movements seek equal protection and nondiscrimination. A number of states have either repealed anti-gay laws or passed new laws to protect gay persons from discrimination. ${ }^{269}$ The 1996 Constitution of South Africa explicitly protects the right to sexual orientation in its bill of rights. ${ }^{270}$

In the last decade, some national, regional, and international organs seem willing to consider a form of protection for gay rights. More than any other region, Europe has been willing to protect gay rights. A number of cases at the European Court of Human Rights have ruled that the European Convention on Human Rights prohibits discrimination against homosexuals. ${ }^{271}$ In an opinion, the UN Human Rights Committee has stated that the reference to "sex" and "other status" in Articles 2(1) and 26 of the ICCPR, respectively, must be taken to include the prohibition of discrimination based on sexual orientation. ${ }^{272}$ This interpretation by the Human Rights Committee has important legal value, but it does not settle the status of gay rights in human rights and international law.

Gay rights have not crystallized in international human rights law. In 1994, gay rights received a major boost when Amnesty International decided to adopt as prisoners of conscience persons imprisoned solely for their homosexuality. ${ }^{273}$ However, Amnesty did not state whether it considered sexual orientation a universal human right. Despite powerful constituencies that are opposed to the recognition of sexual orientation as a human right, global political and normative trends suggest that there is a gathering momentum in favor of gay rights. A normative framework, perhaps in the form of a treaty on sexual preferences and practices, may have to be considered.

269. Wayne Morgan, Identifying Evil for What it is: Tasmania, Sexual Perversity and the United Nations, 19 Melb. Univ. L. Rev. 740 (1994) (analyzing the revision of an Australian law that was deemed to violate the ICCPR). See also Steiner \& Alston, International. Human Rights IN CONTEXT, supra note 18 , at 749.

270. S. Afr. Const., supra note 250 , ch. $2, \$ 9(3)$.

271. Lustig-Prean and Beckett v. United Kingdom, 1999-VI Eur. Ct. H.R. 235; Norris v. Ireland, 142 Eur. Ct. H.R., available at http://www.echr.coe.int/ECHR.

272. Views Concerning Communication No. 488/1992 (Toonen v. Australia), U.N. ESCOR, Comm'n on Hum. Rts., 50th Sess., I 8.7, U.N. Doc. CCPR/C/50/D/488/1992 (1994).

273. Baehr, supra note 244 , at 5 . 


\section{E. Is There a Need for New Strategies?}

The drafters of the UDHR could not have imagined the enormous success of the human rights movement. But actors in the world of standard setting need to pursue more coalitionary, consultative, and participatory approaches to standard setting. These approaches must be crosscutting among states, INGOs, local NGOs, the South, the North, and across social cleavages. The suspicions and exclusions of the past ought to be discarded, so all the key actors can work in unison. NGOs will have a central role to play in this process because they have the energy, interest, expertise, and credibility to push for new standards. The same approaches will be relevant whether one seeks to protect existing standards, revise them, or even push for entirely new ones. It is important for standard-setters to think outside the box, or even against the box, that is, beyond the treaty as the only preferable method for norm setting. The Guiding Principles on IDPs demonstrated the need for such flexibility.

Investment in standard setting remains a critical question. There are many emergent needs, so it seems that clear, substantial investments are still required. These include the area of disabilities, sexual orientation, economic and social rights, and even women's rights. It is true that more resources are also required for implementation. This should not mean that standard setting should be abandoned. If that were the case, the ICC would never have come into being. The creation of a normative edifice is the biggest success of the movement. To be sure, there are still many gaps and weaknesses in human rights standards, and much remains to be done. The movement's failures have been in implementation and enforcement. The good news is that the human rights movement is now an integral part of the human conscience. The bad news is that both new standards and the clarification of existing ones tend to be areas of great controversy and complexity. Standards in the area of civil and political rights are highly developed and sophisticated, while in the field of economic rights progress has been slow, if not static at times.

The right to development, like all group or collective rights, is faced with particularly acute challenges. Standards on terrorism and human rights, sexual orientation, and women's rights provide different challenges. NGOs, the engines that drive the standard-setting processes within IGOs, must learn the lessons of past campaigns, both failures and successes, to craft effective approaches for each of these target areas. The most stubborn of these areas is economic and social rights, and by extension, the right to development. Reluctance characterizes the response of many states, IGOs, and NGOs, particularly INGOs, to standard setting in these rights. Courage, innovative approaches, and new sponsors are needed to overcome the fatigue and disinterest associated with these rights. INGOs must first shed their reluctant embrace of economic and social rights and go beyond the current efforts of 
Amnesty International and Human Rights Watch. However, these two large INGOs will be critical in this campaign. Both should reallocate a considerable percentage of the enormous resources that they put into civil and political rights to economic and social rights. This is justifiable in view of the remarkable successes in standard-setting and the implementation of civil and political rights, on the one hand, and the yawning gap, on the other, in the equally important corpus of economic and social rights.

Reporting and monitoring would tremendously raise the visibility of these rights. The influence and access of INGOs to political and business elites in the North and within multilateral development and finance institutions, such as the World Bank, would soften their opposition. This is an important first step in this campaign. Secondly, INGOs must create a broad civil society coalition with NGOs from the South that have been working on economic and social rights and on the consequences of globalization. Some of these local NGOs have a wealth of experience, expertise, and committed personnel who understand the issues and can articulate the problems that must be addressed by new standards. In the past, such coalitions have been lopsided, with INGOs setting the agenda and determining the priority issues.

There is no need for the adoption of wholly new strategies in the pursuit of standards in some areas where there are gaps, including in women's rights. However, the lessons of the history of standard setting in human rights suggests that large coalitions of INGOs and NGOs should form the nucleus of such campaigns. Secondly, sympathetic states and UN specialized agencies can become important allies and catalysts_-and sometimes leaders-of these campaigns. Mexico on disability rights, Costa Rica on the Optional Protocol to the Torture Convention, and Norway with the Declaration on Human Rights Defenders are classic examples of states that sought leadership in the setting of particular standards. NGO coalitions and sympathetic states are formidable. The Landmines Convention and the Convention on the Rights of the Child are models of such cooperation. It is this formula and levels of commitment that advocates for human rights should cultivate to address the normative lacunae in the human rights corpus. Otherwise, the lacunae in these rights will undermine the success and authority of the human rights movement and threaten its gains. The movement must conquer these new frontiers to remain relevant and to protect its achievements. 